\title{
Consolidating and Contesting Authoritarian Neoliberalism in Turkey: Towards a Framework
}

\author{
Imren Borsuk@, Pınar Dinç®, Sinem Kavak®, \\ and Pinar Sayan 0
}

Abstract During the early years of the ruling Adalet ve Kalkrnma Partisi (Justice and Development Party, AKP), Turkey was seen as a burgeoning democratic power propped up by economic prosperity in

All authors have contributed equally. The author names are in alphabetical order. The authors would like to thank the Centre for Advanced Middle Eastern Studies and the Strategic Research Area (SRA): Middle East in the Contemporary World (MECW) at Lund University for providing the open-access funding for this chapter.

\footnotetext{
İ. Borsuk $(\bowtie)$

Forum Transregionale Studien, Berlin, Germany

e-mail: imren.borsuk@su.se

P. Dinç - S. Kavak

Centre for Advanced Middle Eastern Studies, Lund University, Lund, Sweden e-mail: pinar.dinc@cme.lu.se

(C) The Author(s) 2022

İ. Borsuk et al. (eds.), Authoritarian Neoliberalism and Resistance in Turkey, https://doi.org/10.1007/978-981-16-4213-5_2
} 
line with the reforms for European Union (EU) accession and International Monetary Fund (IMF) conditionality. However, 20 years later, it is considered an emblematic case of democratic backsliding in line with rising poverty and inequalities that have been amplified as a result of sweeping neoliberal reforms and authoritarian consolidation in the country. The recent literature has identified these concomitant and complementary modes of authoritarian governance and neoliberal policies in Turkey as 'authoritarian neoliberalism'. In this chapter, we discuss the dynamics of consolidation of authoritarian neoliberalism in Turkey as well as the acts of contention against it. Building mainly on the eight case studies presented in this volume, we put forward a framework that explains the consolidation of authoritarian neoliberalism in Turkey through the mechanisms of executive centralisation, autocratic legalism, cronyism, violence-fuelled rentier accumulation, criminalisation and stigmatisation, and contestations against authoritarian neoliberalism through strikes, protests, demonstrations, network building, litigation, everyday struggles, and armed acts of contention.

Keywords Authoritarian neoliberalism - Resistance - Contentious politics $\cdot$ AKP $\cdot$ Turkey

\title{
INTRODUCTION
}

On a spring day in 2021, in the mountains of Northern Turkey, yet another protest by the villagers took place to oppose a governmentbacked, company-initiated commercialisation project. A notorious construction company with close ties to the government wanted to establish a quarry in İkizdere Valley—a natural preservation site that witnessed

\author{
P. Sayan \\ Department of Political Science and International Relations, Beykoz University, \\ Istanbul, Turkey \\ e-mail: pinarsayan@beykoz.edu.tr \\ I. Borsuk \\ Stockholm University, Stockholm, Sweden
}


successful grassroots mobilisations throughout the previous decade-for resources to use in the construction of a port that would earn the company two hundred million dollars as tender price. The villagers who mobilised to protect their environment and livelihoods were countered by the forces of gendarmerie and company, an alliance that everyone in Turkey has become accustomed to. In response, the villagers called for help from a not-so-accustomed agent and creatively used beehives to block the roads and stop the excavators. The resistance of the villagers, which also include press statements, demonstrations, strikes, and camping on-site, was soon banned for at least two weeks by the Rize Governor's decision. While the ban continues at the time of writing this chapter, İkizdere remains a site of contentious interaction. Villagers continue to protect the valley at any cost; they receive support from the public through various means, such as social media hashtag campaigns, bar association declarations, the involvement of environmental organisations and activists, as well as international organisations. This rather insignificant instance in the history of contemporary Turkey, when compared to the turbulent events of the last decade, crystalises the forces and counterforces we elaborate in this chapter: commodification, land grabbing, rentier accumulation, cronyism, and violence, as well as resistance with conventional and unconventional means.

The literature on authoritarian neoliberalism questions how contemporary capitalism strengthens the authoritarian tendencies of governments, transforming pre-existing institutions, practices, cultures, and norms into market-oriented power relations (e.g., Bruff, 2014, 2016; Bruff \& Wöhl, 2016; Gonzales, 2016; Smith, 2018; Tansel, 2017, 2018; Wigger \& Buch-Hansen, 2015; contributions in Tansel, 2018; contributions in Fabry \& Sandbeck, 2019; Bruff \& Tansel, 2019; Fabry \& Sandberg, 2019). Demonstrating the spectrum of disciplinary strategies and variegated processes of neoliberal accumulation, these critical studies help us better identify how neoliberalisation unleashes a set of state strategies that insulate economic policies from popular scrutiny and demands. Turkey is considered an emblematic case of authoritarian neoliberalism (Tansel, 2018) which illustrates the consolidation of authoritarian state power in line with neoliberal policies (Bilgiç, 2018; Bozkurt-Güngen, 2018; Kaygusuz, 2018; Özkızıltan, 2019; Yeşil, 2018; contributions in Geniş 2020; contributions in Babacan et al., 2021). While these studies point 
out the crisis-laden character and internal legitimacy problems of authoritarian neoliberal regimes, resistance strategies and practices that underline this political-economic restructuring are understudied.

Using Turkey as an empirical case, this chapter builds on this theoretical background and demonstrates the mechanisms of consolidation and the acts of resistance that constitute the dynamics of authoritarian neoliberalism. Building mainly on the eight case studies presented in this volume, we cover discontents and struggles in a country that is slipping further into authoritarianism. Our analysis cuts across rural-urban divides, class positions, and minorities; we explore gendered and racial impacts, ${ }^{1}$ and local manifestations concerning both relations of production and social reproduction. The chapter also sheds light on popular contentions, grassroots mobilisations, new forms of opposition, everyday struggles, and discourses that negotiate, contest, denounce, and rework the deployment of authoritarian state power in favour of neoliberal policies. Scrutiny of the dynamics of authoritarian neoliberalism informs resistance strategies and helps us understand the prevailing discourses, strategies, and violence that push through subaltern struggles. It is important to note that by authoritarian neoliberalism we are neither defining a regime type nor theorising a total break from mainstream neoliberal regimes of accumulation, all of which are discussed separately in the literature. Instead, we combine analyses of political economy and political science to highlight the concomitant evolution of authoritarianism in line with neoliberal restructuring in the country. Furthermore, we demonstrate the various mechanisms through which people contest, subvert, and escape relations of domination and subjugation to surpass the 'narrative of defeat', identifying the challenges, resistance, and 'fluidity' in the relations of production and subjugation that exist beyond the state and encompass everyday life (Huke et al., 2015, p. 732; Shukaitis, 2007, p. 104).

In the remainder of this chapter, we first turn to the critical scholarship on neoliberalism and examine the role of resistance in challenging authoritarian neoliberalism. We then demonstrate the dynamics of authoritarian neoliberalism in Turkey by discussing the mechanisms of its consolidation and contestation.

\section{Authoritarian Neoliberalism and Its Contestation}

Before we begin our analysis of the contentious interaction between authoritarian neoliberalism and its contestation in Turkey, we briefly 
explain what we mean by these two concepts and how they are discussed in the existing literature. As discussed by the extensive literature on neoliberal capitalism, the striking feature of contemporary capital accumulation is neither its adherence to the free-market nor open trade but its overarching capacity to penetrate various arenas of everyday life (e.g., family, neighbourhood, city) and domains of life including economy, urbanisation, ecology transforming the pre-existent practices, cultures, and norms into market-oriented power relations (Brown, 2015; Crouch, 2011; Demmers et al., 2004; Dumènil \& Lèvy, 2004; Harvey, 2006; Joseph, 2013; Ong, 2006; Turner, 2011). While neoliberalism as a concept has been criticised for being a buzzword lacking real explanatory power to understand these overarching impacts (Birch, 2015, 2017; Dunn, 2017; Venugopal, 2015), scholars propose to see neoliberalism not as a ubiquitous and omnipresent external force operating at the global level but as a variegated and mutable process in interaction with nationalpolitical contexts (Peck \& Tickell, 2002). With specific attention to this variegated nature, authoritarian neoliberalism emerges as a concept to scrutinise the coupling of neoliberalism with authoritarianism and capture this recent trend that has amplified particularly after the 2007-2008 global economic crisis. One of the earlier attempts in this vein is by Bruff (2014) who underlines an increase in the punitive nature of penal and criminal policy 'through the move away from seeking consent for hegemonic projects' (p. 116, emphasis in original). Further developing the concept, Tansel $(2017$, p. 3$)$ posits that authoritarian neoliberalisms:

1. operate through a pre-emptive discipline which simultaneously insulates neoliberal policies through a set of administrative, legal, and coercive mechanisms and limits the spaces of popular resistance against neoliberalism (Bruff, 2014, p. 116);

2. are marked by a significant escalation in the state's propensity to employ coercion and legal/extra-legal intimidation, which is complemented by intensified state control over every sphere of social life ... (and) draconian and multiform curtailment of so-called “formal” liberties' (Poulantzas, 1978/2014, pp. 203-204).

Acknowledging critiques that emphasise the inherent tendency of neoliberalism to become authoritarian (Walby, 2018) and the concept's porous 
analytical boundaries that recall the interweaving of authoritarian practices with capital accumulation in previous periods (Fabry, 2019; Ryan, 2019; Schneider \& Sandbeck, 2019), we contend that the theorisation of authoritarian neoliberalism is empirically, analytically, and politically necessary. While neoliberal capitalism entered into a phase of stagnation from 2008 onwards with increasing austerity measures, deteriorating wages, insecurity of working classes, and aggressive dispossession in favour of extractive industries (Bruff, 2014; Bruff \& Tansel, 2019), there has also been a violent suppression of public protests and dissenting groups, erosion of the rule of law, and democratic backsliding in both advanced and developing capitalist economies (Freedom House, 2018). It is necessary to give analytical attention to the variegated nature of neoliberalism and how its reproduction is attached to particular material cultures that give rise to different manifestations in everyday life (Fine \& Saad-Filho, 2017). As Peck and Tickell state, 'the purposeful construction and consolidation of neoliberalized state forms, modes of governance, and regulatory relations' have the potential to foster 'a radical, emergent combination of neoliberalized economic management and authoritarian state forms, that demands both analytical and political attention' (2002, p. 384, emphasis in original). Furthermore, we argue that authoritarian resurgence cannot be reduced to a simple political transition as it is blended with rationalities of political economy that affect and are affected by local, regional, national, and global processes. In this respect, the authoritarian neoliberalism framework helps us better demonstrate how the material interests, expectations, and life chances of different social groups and classes are transformed during the process of neoliberalisation and the concomitant rise of authoritarian practices and discourses that seek to subjugate and dominate underlying struggles and tensions.

The symbiosis of neoliberal restructuring with authoritarian resurgence has set off a series of protests and social unrest in many parts of the world. Contestations against neoliberal policies have taken many (individual, collective, and institutional) forms ranging from transnational movements (e.g., the Occupy movement, anti-globalisation movement) and nationwide protests (e.g., Spain's Indignados, Turkey's Gezi protests) to local organisations (e.g., anti-gentrification neighbourhood organisations) and individual acts of survival. The fact that many episodes of contentions ended up being similar, from the USA, France, and the UK to Turkey, India, and Brazil, with governments portraying protesters as extremists and mobilising coercive and punitive power against popular pressures, 
confirms the trends of rising authoritarian neoliberalism all over the world (Bruff, 2014). Thus, contemporary counter-hegemonic movements not only contest austerity policies but also the crisis of democracy to tackle the intertwined crises of neoliberal economy and democracy (Flesher Fominaya, 2017). Engaging in 'insurgent performances', people resist the inequalities of the political and economic system (Holston, 2009, p. 250), mobilise for their right to the city, participate in grassroots political activism (Bastia \& Bressán, 2018), and bypass the limitations of formal and mostly partisan politics. Although these diverse acts of contestation cannot be simply grouped under the loose generic of 'resistance', they help us observe the 'extraordinary array of struggles unleashed by accumulation by dispossession' (Hart, 2006, p. 983).

The social bases of new anti-capitalist social movements like the Global Justice Movement and anti-austerity movements are also changing, as they are composed of class coalitions and the precariat as a result of the continuing downward pressure on wages and precarisation of working classes (Della Porta, 2015). This heterogeneity of the social base leads us to consider the importance of intersectionality and 'pluralist and tolerant identities' in new social movements (Della Porta, 2015, p. 62) that are demanding deliberative and/or direct democracy. This interplay between economic and cultural factors has become increasingly visible in recent social movements and implicated in the struggles for both redistribution and recognition (Masquelier, 2017). Thus, emancipatory political action should build around a sense of unity in diversity, using intersectionality (Hill Collins \& Bilge, 2016), as subaltern groups are not only composed of the working class but are also divided by the multiple and intersecting relations of power and difference like class, gender, and race or ethnicity that need to be given specific attention while considering the transformative potential of resistance movements (Casolo \& Doshi, 2013, p. 805).

To understand contestation against authoritarian neoliberalism, we benefit from social movement frameworks at the intersection of sociology, political science, and disruption-oriented critical political economy (CPE). The CPE approach underlines the importance of looking at the everyday activities and resistance of workers as an important counter-hegemonic and disruptive action against global capital accumulation, unravelling 'instances of contestation, disruption and struggle' (Huke et al., 2015, p. 745), even if they do not necessarily dominate the system. However, we also find other related approaches, such as the Gramscian framework 
of hegemony, important in explaining the phenomenon. Building on the disruption-oriented CPE framework offered by Huke et al. (2015; see also Bailey et al., 2021), Las Heras (2019, p. 227) provides a 'sympathetic critique' and offers a third alternative called the 'Gramscian or strategic International Political Economy of Labour (IPEL)'. This approach is hybrid and does not reify one scale over the other; rather, it sees the interconnectedness between different scales. Using Gramsci's 'Methodology of the subaltern', Las Heras (2019, p. 240) explains how workers 'both present an objective challenge to bourgeois domination while they also reproduce new forms of capitalist hegemony owing to their inability to produce effectively alternative paths'. While a comprehensive Gramscian analysis of hegemony is beyond the scope of this chapter, it is still possible to find hints of hegemony in our analysis of the instances through which the state generates consent. This enables us to gain a deeper understanding of people's co-optation, integration, and silencing in the face of multiple modes of domination.

Furthermore, it is important to remember that resistance in authoritarian contexts has often been an uncertain and complex issue given institutional limitations and coercive policies. As Adaman et al. (2019, p. 517) rightly argue, there is a 'vast grey area between a successful hegemonic project based on societal legitimacy and an open contestation of state rule' that should be considered in authoritarian regimes. Contestation against authoritarian forms of neoliberalism can occur in covert and disguised forms even when societal opposition is largely invisible, particularly while institutions are closed to popular demands. It is thus necessary to explore the 'politics of the governed' (Chatterjee, 2004), people's creative strategies to become part of political society and expand democratic possibilities. As studies on political sociology and social movements unravel, people's everyday resistance can undermine the hegemonic economic order in creative and innovative ways, such as the 'hidden scripts' of powerless peasants against their oppressors (Scott, 1985), the efforts of indigenous groups to be self-sufficient using 'articles of everyday life' (Levi, 1998) or the urban poor's 'quiet encroachment of the ordinary' carving out space in the city by their everyday acts (Bayat, 2000).

However, resistance is not detached from the political-economic regulatory environment, market-oriented practices, and values that meander through resistance claims, strategies, and discourses. The literature on resistance against neoliberalism demonstrates that there is a global trend 
of 'NGO-isation of resistance', adopting the rationality and norms of the neoliberal order that NGOs are embedded in (Coleman, 2013; Korolczuk, 2016; Roy, 2014). Local struggles also reflect neoliberal discourses projecting corporate culture in their organisation and management (Bhatia \& Priya, 2018). Even the intellectual currents that advocate counter-hegemonic and progressive causes may end up endorsing the utilitarian, pragmatic thinking of the neoliberal order (Rutherford, 2018). It must be also noted that resistance should be seen as multifaceted and not necessarily as emancipatory or progressive, like the rise of right-wing populism that capitalised on the popular frustration with neoliberal policies (Konings, 2012). It can also be used as an opportunity by dominant forces to adjust to growing social discontent, such as through the internationalisation of penal policies from the USA into Western Europe based on the criminalisation of poverty (Wacquant, 1999).

\section{The Dynamics of Authoritarian Neoliberalism in Turkey}

Within this conceptual framework and background, our analysis explores the dynamics of authoritarian neoliberalism in Turkey under the AKP through the mechanisms that consolidate it and the acts of contestation through which people resist the authoritarian neoliberal state (Fig. 2.1).

Building on the legacy of the previous periods, authoritarian neoliberalism in Turkey has been consolidated during AKP rule via its dominant party position. There has been an alignment between neoliberal transformation and the deepening of authoritarianism under the AKP governments in Turkey, which have reinforced the state's coercive, legal, and administrative powers and insulated neoliberal policies from popular demands. We put forward that authoritarian neoliberalism in Turkey functions through five intertwined mechanisms: (1) executive centralisation, (2) autocratic legalism, (3) cronyism, (4) violence-fuelled rentier accumulation as well as (5) criminalisation and stigmatisation.

The first two mechanisms, executive centralisation and autocratic legalism, go hand in hand and reflect the arbitrary, on-demand tampering with the institutional structure and legal realm. The third mechanism, cronyism, refers to the distribution of political power and economic value among government-oriented business, political and civil society groups. We defined violence-fuelled rentier accumulation as the fourth mechanism, where we observe processes of both value creation and its 


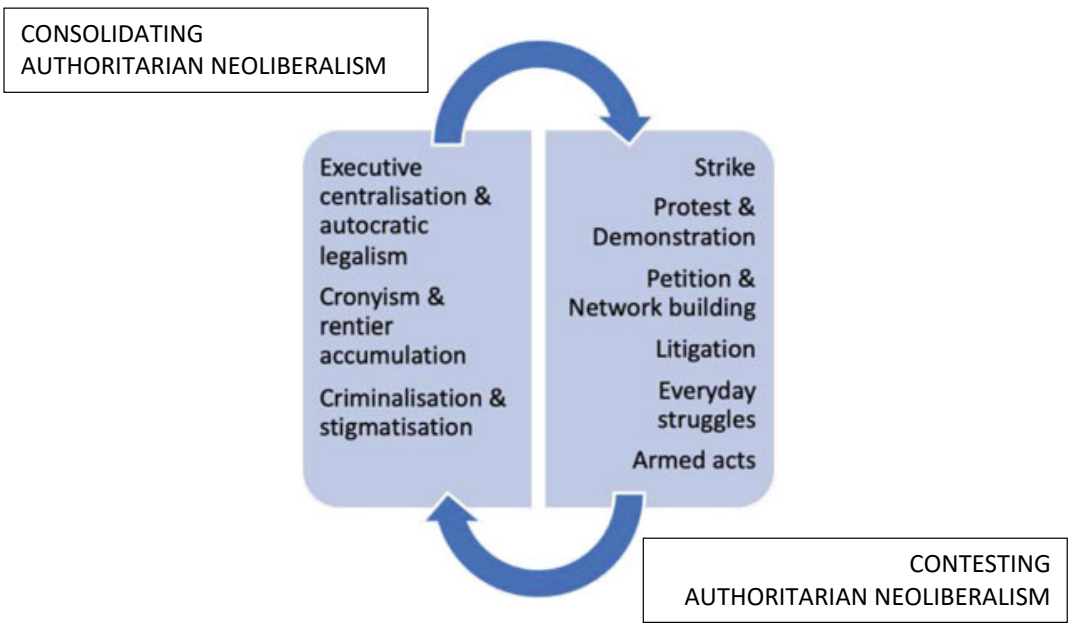

Fig. 2.1 The contentious interaction

distribution. Lastly, criminalisation and stigmatisation are crucial mechanisms used not only to suppress opposition but also to underpin consent among the AKP's constituency.

The consolidation of authoritarian neoliberalism in Turkey is not without resistance. We discuss six different methods through which authoritarian neoliberalism in Turkey is contested. Resistance may be grassroots or social movement activist-led mobilisations, which work through strikes, protests, demonstrations, petitions, network building, and litigation against authoritarian neoliberal policies. There are also everyday forms of resistance that stem from people's struggles to sustain their livelihood. We also note that, although limited in number, there are instances of armed contention against authoritarian neoliberal policies by pre-existing armed groups.

The dynamics between the consolidation and contestation of authoritarian neoliberalism, we describe above, operate simultaneously and interact under authoritarian neoliberalism; a process that we define as contentious interaction. What we intend to do here is to specifically map out the interactions between these factors to draw out statecapital-society relations. The rest of this chapter discusses the intertwined economic, legal, political, and societal factors of the consolidation and 
resistance against authoritarian neoliberalism during the AKP period. Our analysis mainly relies on the eight case studies presented in this volume, but we have also drawn on other cases when necessary to complement the analysis. We underline the roles that gender, class, and ethnicity play in both how authoritarian neoliberalism mechanisms are implemented and challenged. We combine results from sites of production (i.e., the Greenhouse) with multifaceted sites of commodification (i.e., rural and urban commons, education) and emerging spaces and forms of resistance and survival (i.e., media, civil society). Although we give specific examples of the different mechanisms of consolidation and contestation of authoritarian neoliberalism in Turkey through different case studies, we want to underline that often, if not always in these cases, several mechanisms of consolidation and contestation are used concurrently.

\section{Consolidating Authoritarian Neoliberalism}

Unlike in the early 2000s, when the academic literature was mostly focussing on democratisation in Turkey (Hale \& Özbudun, 2011; Insel, 2003; Özbudun, 2006, 2007), recent studies have dealt with its autocratisation. A largely accepted argument is that Turkey has experienced a transition from a defective democratic regime to a version of either a more defective democracy or authoritarianism (Akkoyunlu \& Öktem, 2016; Başer \& Öztürk, 2017; Çalışkan 2018; Castaldo, 2018; Esen \& Gumuscu, 2016; Öktem \& Akkoyunlu, 2016; Öniş, 2013; Özbudun, 2014, 2015; Somer, 2016; Sözen, 2008, 2010, 2020b; Taş, 2015; Türkmen-Dervişoğlu, 2015; Tuğal, 2016). Although the number of the studies that focus on the AKP's 'authoritarian turn' has significantly increased, particularly since the Gezi protests in 2013, some observers point out that authoritarianism was present much earlier (Atasoy, 2020; Babacan et al., 2021; Bakıner, 2017; Erensü \& Alemdaroğlu, 2018; Sözen, 2008, 2020a; Taşkın, 2013). The extant research on the AKP also underlines the similarities of the existing regime to previous periods in Republican history such as neoliberal economic management (Adaman \& Akbulut, 2020; Akça, 2014; Atasoy, 2020; Babacan et al., 2021; BozkurtGüngen, 2018; Özden et al., 2017; Özkızıltan, 2019; Madra \& Yılmaz, 2019) or majoritarian understandings of democracy (Akça, 2014; Babacan et al., 2021; Özden et al., 2017; Somer, 2016; Sözen, 2020b).

Borrowing the 'construction and consolidation of neoliberalised state forms' framework coined by Peck and Tickell (2002) (and later Theodore 
et al., 2012), Geniş (2020, p. 18) claims that it is possible to define the period before 2002 as the 'construction of neoliberal state' and the period after 2002 as the 'consolidation of neoliberal state' through building the institutions of Islamist neoliberalism and the deepening of marketisation and commodification. As argued by Bedirhanoğlu, "the radical state transformation after 2013 in Turkey needs to be problematised not as a "turn" but in continuity with the Islamist AKP's powerful integration to the global neoliberal agenda with its own specificities since 2002' (2021, p. 79). While not rejecting the pre-AKP roots of convergence between authoritarianism and neoliberalism in Turkey, we argue that authoritarian neoliberalism in Turkey has been consolidated during AKP rule via its dominant party position. The consolidation of neoliberal economic policies is also intertwined with Islamic and/or conservative elements, as emphasised by various studies (Babacan et al., 2021; Bilgiç, 2018; Kutun, 2021; Madra \& Yılmaz, 2019; Özden et al., 2017).

The authoritarian neoliberal consolidation of the AKP has relied on a variety of coercive and consent-generating mechanisms. The AKP still has the potential for consent generation via various mechanisms and discourses, as election and referendum results demonstrate. The AKP's electoral popularity among the masses, who are the ones most harmed by neoliberal economic policies, is explained through neoliberal populism by critical political economists (Adaman \& Akbulut, 2020; Akçay, 2018; Bozkurt, 2013; Özden, 2014; Ylldırım, 2009), and the evergrowing literature on the topic discusses different dimensions of AKP's populism (Aytaç \& Öniş, 2014; Castaldo, 2018; Dinçşahin, 2012; Selçuk, 2016; Sözen, 2019; Yabanc1, 2016; Yabancı \& Taleski, 2018). However, populism is not one of the dimensions examined by the contributions to this volume. Therefore, by sticking to the findings of the contributions for this chapter, we focus on the co-optation and coercion mechanisms that the AKP has been employing to consolidate its authoritarian neoliberal power.

\section{The Twin Forces of Executive Centralisation and Autocratic Legalism}

At the heart of authoritarian neoliberalism lay legal changes that include constitutional changes and administrative transformation to provide market-driven reforms and economic efficiency (Bruff, 2014; Tansel, 2017). Although Turkey witnessed neoliberal reforms during the 1980s, ${ }^{2}$ 
large-scale legal reforms coincided with the EU accession process and IMF-led structural adjustment programmes in the late 1990s and early 2000s. Emboldened by the high growth rates during the early periods of the AKP government and EU harmonisation reforms, the AKP increased its support and engaged in consolidating its power through eroding the rule of law and weakening the separation of powers in Turkey. The legal changes that were put into place to 'rationalise' and 'reform' the state and economy allowed the executive to subjugate the legislature and the judiciary and entrench elite networks of political and economic circles in positions of power with legal rights to control rents and material rewards. Hence, the constitutional changes initiated by AKP and their promotion as part of the reform wave by government circles did not lead the way to democratisation.

In September 2010, the AKP held a referendum on constitutional changes that would revise the structures of the Constitutional Court and the High Council of Judges and Prosecutors. The constitutional changes were accepted by $58 \%$ of the votes. The two institutions were expanded and the parliament (dominated by the AKP) acquired more power to appoint senior judges and prosecutors. Together with the Ergenekon and Balyoz trials against the military establishment, the constitutional changes also diminished the role of the military in politics (see Akkoyunlu \& Öktem, 2016; Castaldo, 2018; Esen \& Gumuscu, 2016; Özden et al., 2017 for the details of Ergenekon and Balyoz trials). In April 2017, another referendum on constitutional changes was held and accepted with $51.41 \%$ of the votes. With these results, Turkey transitioned from a parliamentary to a presidential system. In the new system, the powers of the parliament are de jure curbed in favour of the executive, while the structures of the Constitutional Court and the High Council of Judges and Prosecutors are further changed. ${ }^{3}$ Thus, the separation of powers and the checks and balances were severely eroded against the power of the executive.

The combination of constitutional changes, lengthy dominant party rule, and the rise of the presidential system and presidential rule by decrees drove executive centralisation. Executive centralisation is a major indicator of authoritarianism and functions as the political background for other factors. To explain this process, Bermeo (2016, p. 10) uses the concept of 'executive aggrandizement', which is defined as '... elected executives weaken checks on executive power one by one, undertaking a series of institutional changes that hamper the power of opposition forces 
to challenge executive preferences'. The centralisation of administration made it possible for the AKP to initiate and pass numerous laws and legislative amendments without the meaningful participation of opposition parties or social groups or supervision of the legislative and executive branches. ${ }^{4}$ This executive centralisation is personalised through the President, which is defined as 'hyperpresidentialism' (Sözen, 2019; see also İnsel, 2017 for personalisation).

As hinted above, the supremacy of the executive is an institutional legacy for Turkey. Building on this legacy, the AKP as the dominant party effectively diminished the role of the parliament and parliamentary debate, particularly when it started to use decrees in 2011 (Taş, 2015, p. 780). Numerous emergency decrees were passed in the aftermath of the coup attempt in 2016. The legality of the emergency decrees within that period is highly controversial for two basic reasons: they regulated matters that were not related to the reasons of declaration of the state of emergency and they remained in power even after the termination of the state of emergency (Akça et al., 2018; Yılmaz, 2020). This 'rule by decree' continued with presidential decrees once the presidential system was established.

The government's relationship with legality can be defined as autocratic legalism, as coined by Corrales to describe autocratisation in Venezuela, referring to 'the use, abuse, and non-use [...] of the law in service of the executive branch' $(2015$, p. 38). Corrales argues that using the law entails 'empowering the executive branch at the expense of the other branches of the government', abusing the law denotes the 'inconsistent and biased implementation of the laws and regulations', and non-using the law includes 'the reliance on illegality especially for the electoral politics' (2015, pp. 38-45). This autocratic legalism gave the AKP government a large margin of manoeuvre to introduce new laws and legal norms or abuse and ignore existing laws to further its policies.

In Chapter 8, Özen and Körükmez provide an example of 'using the law' when the competence of appointing university presidents was given only to the President in 2016 by an emergency decree. Their discussion on the situation of the peace academics is a well-established example of the use, abuse, and non-use of the law. In Chapter 6, Kutlu shows a case of 'abusing the law' in construction of hydroelectric power plants. Urgent expropriation is defined in law but only as an extraordinary measure that the state can resort to under emergencies, such as homeland protection or situations whose urgency would be decided upon by the President of 
the Republic. Under the autocratic legalism of the AKP, it has become a frequent measure for land grabbing and accelerating construction projects including mines and powerplants.

In Chapter 4, Taş demonstrates how laws are designed for socio-spatial interventions in conflict areas. Law no. 2942, for example, addresses 'the urgent expropriation of risky areas for national defence' and is designed as a mechanism of revanchist urbanism to displace and dispossess oppositional communities, such as the Kurdish populations living in Sur. The implementation of the law is also facilitated by executive centralisation, as Halklarm Demokratik Partisi (Peoples' Democratic Party, HDP) municipalities are replaced by top-down appointed trustees and the state housing administration, Toplu Konut İdaresi Başkanliğı (Housing Development Administration, TOKİ), implemented the urban transformation project. The urban transformations law that declared certain areas as regeneration zones, due to earthquake risk or under the auspices of physical decay (Dinçer, 2011; Güzey, 2016), has been instrumental in expanding the operations of the TOKI and the construction sector. An example of 'nonusing the law' is the case of the urban transformation of Sulukule. The historic İstanbul neighbourhood of Sulukule had been the home of Roma since Byzantium times. However, in 2006, urban transformation in the neighbourhood started under Law no. 536, which opens the way for reconstruction of historical properties, despite the protests of residents. Two court rulings in 2012 and 2019 overruled the urban transformation projects but by then the neighbourhood had already been demolished and rebuilt.

Non-compliance with the European Court of Human Rights (ECtHR) decisions about the release of Selahattin Demirtaş and Osman Kavala set other examples of 'non-using the law', but non-compliance in these cases was justified through the introduction of new legal norms. Therefore, we may add a fourth dimension to Corrales's definition of autocratic legalism: the introduction of new legal norms. In 2021, the Chief Adviser of President Mehmet Uçum introduced two legal norms; primacy [birincillik] and guiding review [yönlendirici denetim]. He claims that national sovereignty, therefore national courts, are superior to international courts based on the primacy principle and in accordance with the principle of the guiding review, the decisions of the Constitutional Court or the ECtHR are guiding, not binding (Independent Türkçe, 2021; see also Türmen, 2021; Gözler, 2016). Uçum repeated the principle of guiding review 
when the local court did not comply with the decision of the Constitutional Court about Enis Berberoğlu. The local court, on the other hand, preferred to justify its decision through a controversial interpretation of the subsidiarity principle. ${ }^{5}$ One reason for the introduction of new legal norms was to undermine international law or, to put it differently, undermine legal control over the AKP's policies. As the AKP secured the supremacy of the executive over the judiciary and legislature in domestic politics, Turkey's international commitments provide one of the final, albeit weak, checks to its autocratic rule. ${ }^{6}$

\section{Violence-Fuelled Rentier ACCUMUlation AND CRONYISM}

The neoliberal regime of accumulation since the $1980 \mathrm{~s}^{7}$ has gained momentum during AKP rule in Turkey through rapid rentier accumulation based primarily on the commodification of space and commons (Boratav, 2013; Erensü, 2018; Kavak, 2016). The process is often contextualised as a form of primitive accumulation and/or accumulation by dispossession since construction, energy, and extractive industries are the drivers of Turkey's accumulation. The AKP's economic model has been described as 'real-estate-driven growth' (Aksoy, 2012), 'accumulation through construction' (Purkis, 2016), and 'accumulation through excavation and enclosures' (Madra, 2016). The commodification of land towards infrastructural projects and commercial agriculture is key to capital accumulation (Atasoy, 2020).

Primitive accumulation takes myriad forms along with the development of new forms of environmental, rural, and urban governance that allow the private appropriation of the conditions of production or the privatisation of public goods, resources, and commons. Alongside primitive accumulation, other forms of rentier accumulation are also observable with more complex financial, commercial, and labour patterns. Contributions in this book shed light on the economic and 'extra-economic' conditions of accumulation, focussing on the role of the state in capital accumulation and dispossession using both autocratic legalism and state violence to sustain rentier accumulation and its crony distribution. By extra-economic conditions of accumulation, we follow the tradition referring to forms of accumulation by means other than expanded reproduction such as primitive accumulation, new or ongoing 
forms of accumulation by dispossession, and the gendered and racialised forms of accumulation within social reproduction (Glassman, 2006).

The chapters of this volume exemplify the multifaceted linkages between autocratic legalism and executive centralisation that facilitate neoliberal accumulation. In line with the neoliberal transformation of the economy, state power has been reorganised and produced new laws to commodify lands and resources, while monopolising the supervision and monitoring of the capital accumulation process. As many of the contributors in this book demonstrate, while the government passed new laws and regulations to build the judicial infrastructure of market-oriented reforms, it actively monitored and regulated the capital accumulation process through regulatory and supervisory agencies that centralised power in the hands of the state. For example, the large literature on urban and environmental transformations shows that state regulatory agencies like TOKI and Enerji Piyasası Düzenleme Kurumu (Energy Market Regulatory Authority, EPDK) have played a crucial role in administering lucrative urban and environmental projects and disorganising and silencing popular grievances in favour of the private sector. Moreover, autonomous agencies that were established to regulate different sectors of the economy in the framework of the IMF's structural adjustment programme became subject to continuous legal amendments through executive centralisation and autocratic legalism. An amendment to the law regulating the Merkezi Finans ve İhale Birimi (Agency on Public Procurements and Tenders) is significant in this regard. The law was amended 29 times by the end of 2013 to manipulate the delivery of tenders (Boratav, 2016).

TOKI has had a central role in facilitating urban transformation projects by containing, integrating, or overriding the objections and demands of residents. Two chapters in this volume illustrate two very different urban transformation cases in Turkey. In Chapter 5, Bayurgil presents the case of an elite neighbourhood in İstanbul while in Chapter 4, Taş presents the case of a lower-class Kurdish neighbourhood in Diyarbakır. The post-conflict neoliberal urban transformation of the Sur district in Diyarbakır is an exemplary case of rentier accumulation by dispossession under authoritarian neoliberalism. Through this case, Taş presents the superposing of legal and coercive state apparatuses to displace and dispossess resistant neighbourhoods in Kurdish-dominated cities after the urban warfare of 2015 and 2016. He shows how violent displacement is legitimised by the national security discourse against these particular neighbourhoods inhabited by low-income Kurds, which was 
used to override residents' pre-existing objections to urban development plans. The majority of the houses in the neighbourhood were urgently expropriated by the state, and the remaining residents were deterred by months-long electricity and water cuts. Newly built houses are placed on the market at a price of at least twenty times the compensation paid to displaced ex-residents.

The case study presented by Eren in Chapter 3 demonstrates how neoliberal consolidation paved the way for land and water grabbing, coupled with capital accumulation based on the exploitation of female labour. She follows the literature on neoliberal agrarian transformation in Turkey (Keyder \& Yenal, 2011) and shows how a long-awaited large-scale, plantation-like, intensive farming facility emerged in Western Turkey, an area known for the persistence of small peasantry. Her research begins from the ruins of small tobacco livelihoods that were hit by the infamous Tobacco Law of 2002 during the peak of the neoliberal consolidation process accelerated under the IMF programme. The law transformed the region and resulted in the proletarianisation of female labour. The Greenhouse, with well-established links to global fresh fruit and vegetable value chains, was made possible by the transfer of common land, which was previously used for grazing by the peasant households, to a company through crony relations, in which the municipality was instrumental. Similarly, the usership rights of geothermal water sources in the vicinity were also transferred to the company, providing cheaper heating costs at the risk of disrupting the water-dependent ecosystem and livelihoods.

Similar developments took place in energy production with the Electricity Market Law enacted in 2001. The law enabled private entrepreneurs to build, own, and operate power plants, thus privatising rivers (Erensü, 2013; Kavak, 2016). Furthermore, the Environmental Impact Assessment Bylaw (Çevre Etki Değerlendirme Yönetmeliği, ÇED) was amended to increase the authority of the Ministry of Environment, an intrinsically political governmental body, over the requirements for critical construction projects with environmental impacts, including airports, highways, power plants, refineries, and factories. In Chapter 6, Kutlu shows how the proliferation of hydropower plants (HPP) has played an important role in the threefold increase in Turkey's installed electricity production capacity between 2000 and 2020 (TEIAŞ, 2020), as the energy sector became a major area of economic activity. Proliferation of run-of-river small hydropower plants (SHPs) has also contributed to 
this increase. There are approximately 1000 SHPs under different stages of construction in Turkey (Kavak, 2020), which is another manifestation of land and water grabbing. As a result of these projects, access to rivers, irrigation water, and land around the installations have been seriously limited, including the customary land deemed sacred by the locals. Chapter 6 is a representative case in which even private property rights have been overridden by urgent expropriations to protect the interests of a handful of energy and construction companies with crony ties to the government.

In the education sector, as exemplified in Chapters 7 and 8 , the Yükseköğretim Kurulu Başkanliğı (Ministry of Education and the Council of Higher Education, YÖK) have applied policy changes that go hand in hand with the aims of a conservative transformation of education, the incorporation of state-affiliated enterprises into the education market, and the global financialisation of the education sector with increased international investment. The education policies of the AKP aimed to re-Islamise society in a neoliberal fashion with pro-government capital finding the means to make substantial profits in the form of private schools, dershane (private tutoring centres) and the publication of textbooks and other materials (Kandiyoti \& Emanet, 2017; Türkmen, 2009). Another process we observe in the transformation of the educational system is the commodification of higher education. The number of foundation universities has tripled under AKP rule, accompanied by the precarisation of academic labour and budget cuts under the policies of financial autonomy. ${ }^{8}$

Decree laws (both under the state of emergency and presidential decrees) have been instrumental in asset transfers. During the state of emergency declared after the failed coup d'etat of 2016, universities, foundations, schools, hospitals, trade unions, and media corporations have been confiscated by the government and their assets transferred to the Ministry of Treasury and Finance and Vakıflar Genel Müdürlüğ̈̈ (Directorate General of Foundations). The directorate has overseen the transfer of over a thousand historical landmarks-including the land of Topçu Kışlası (Taksim Military Barrack), also known as Gezi Park-to fused foundations (mazbut vakuflar).

Similarly, the Türkiye Varlık Fonu (Turkey Wealth Fund Management Corporation), chaired by the President of the Republic, was established in August 2016 with the inclusion of profitable state-owned enterprises (Pinar, 2021, p. 38). As Kutun notes, the affiliation of the public 
resources of the Wealth Fund with the presidency facilitated the merging of close circles of the President with capital groups and grew their influence over ministries responsible for economy management. This reinforced the discretion of the executive body over the management and spending of the resources gained from public assets (2021, pp. 57-58). The Wealth Fund was authorised to regulate the assets of major and strategically important state-owned enterprises (including banking, petrochemistry, satellite and telecommunication services, and mines) and the privatisation of others (such as Turkish Airlines). Moreover, the Wealth Fund is not supervised by the Sayıștay Başkanliğı (Turkish Court of Accounts).

The AKP couples coercive strategies with strategies of co-optation. Within this highly inegalitarian conjuncture, cronyism emerges as a sui generis mechanism through which rents from rentier accumulation are distributed between firms, political interest groups, and certain social cleavages to generate consent. Cronyism in Turkey generally manifests itself in four different ways: delivering high-budget public tenders to a few pro-government business groups along with frequent tax-pardons; donations by these groups to government-oriented non-governmental organisations (GONGOs), which are also financially supported with public funds (Yabanc1, 2019); appointing relatives and people from government circles to important roles both in public and private sectors; and distributing fractions of rents to people to co-opt public opposition.

The public procurement system has been a significant arena in which relations between pro-AKP enterprises and the state developed. The oftmade amendments and exception clauses in public procurement laws have enabled arbitrary decision-making and a lack of supervision in public procurement (Borsuk, 2017, pp. 102-103; Gürakar, 2016). A quick look at state tenders reveals that only a handful of companies receive infrastructure investments with very high budgets, known as megaprojects. According to World Bank data (2020), Turkey has five companies on the global top-ten list of companies that receive public bids. These companies engage in construction (roads and airports), electricity production, and natural resource extraction, sectors in which the majority of rentier accumulation and dispossession take place. In Chapters 3, 4, and 6, Eren, Taş, and Kutlu, respectively, demonstrate this favouritism to certain business groups.

Media ownership is another area in which the crony business relations of the government prevail. The most significant example in this regard 
is the confiscation of the ATV channel and Sabah newspaper (two key parts of the mainstream media) in 2007. These two media outlets were then bought by a large company active in the construction and energy sectors, known for its affinity to the ruling party. Moreover, the company used credit from public banks with low interest rates for the purchase. The former CEO of the holding, Berat Albayrak, is the son-in-law of President Erdoğan and has served in critical positions in AKP ranks as well as state departments, such as the Ministry of Energy and Natural Resources and the Ministry of Treasury and Finance. Privatisations and financialisation in the media sector have resulted in the concentration of media ownership within a few business groups, making it an economically lucrative and politically convenient tool for the manipulation of public opinion. Moreover, critical journalists and media outlets have been deterred by precarisation, coercion, threats, and prosecutions (Çı̆̆ \& Çı̆̆ 2021).

The AKP is also known for forming and supporting partisan organisations in civil society. In addition to the coercive mechanisms that are used to oppress the independent voices, the AKP forms new organisations or supports those that already exist, and business groups contribute to this process through donations. In Chapter 10, Yabanc1 demonstrates how authoritarian neoliberalism has pushed civil society to develop vertical ties with governments and how authoritarian regimes have re-politicised civil society through the establishment of government-oriented civil society organisations (see also Hasmath et al., 2016). While many NGOs and activists have been prosecuted, the AKP has supported organisations with organic links to the party (Yabanc1, 2019). Yabanc1 also highlights a new law called 'Preventing Financing of Proliferation of Weapons of Mass Destruction', which is used to curb the legal activities of civil society organisations (see also Özdoğan, 2021).

As the state withdrew from social welfare provision and social aid replaced institutionalised forms of social security, GONGOs became instrumental in distributing social aid to generate consent. Social aid is used to prevent the alienation of the impoverished rural and urban poor (Eder, 2010; Yükseker, 2009). Clientelistic networks have become instrumental in the distribution of aid (Adaman \& Akbulut, 2020; Akçay, 2018; Buğra \& Candaş, 2011; Buğra \& Keyder, 2006) and served to portray Erdoğan as the patrimonial benevolent figure in a 'charity-based social model' to generate consent (Ünsaldi, 2013).

In Chapter 5, Bayurgil maintains that consent generation does not always take place in a crony fashion-class is another important factor. 
Elaborating on urban transformation in an upper-class neighbourhood in İstanbul, she shows that secular upper classes consent to neoliberal urban transformation because it aligns with their class interests. As Bayurgil highlights, residents also engage actively in rent-seeking through these projects in search of lucrative contracts and profits, giving overt or covert approval for capital accumulation. The urban transformation in Kadıköy, İstanbul, and concurrent capital accumulation by relocated residents serve to reaffirm their social status in the changing economic environment, despite their criticism of the government's authoritarian neoliberal urban policies. By this, Chapter 5 shows how state actions have varying consequences for different socio-economic groups and underlines how privileged groups' desire for upward mobility may result in a lack of resistance (or the existence of consent), even though they discursively frame their position against the government.

\section{StigmatisATION AND CRIMINALISATION}

Although she does not write on authoritarian neoliberalism per se, Wendy Brown $(2019$, p. 108) puts forward that neoliberalism is equally invested in what she calls the extension of traditional morality, which she defines as 'installing markets and morals where society and democracy once were'. The erosion of the mechanisms of consent, executive centralisation, and a greater emphasis on traditional morality undermines citizenship rights to advance marketisation. Across different countries, such as Cambodia, India, and Brazil, we see the justification of neoliberal policies under narratives of order, stability, and economic prosperity, while governing elites undermine popular discontent through an upsurge of populism, authoritarianism, and nationalist discourses (Chacko, 2018; Saad-Filho, 2020; Springer, 2009). As a result, we observe exploitative capitalist relations of property, labour, and resources in inextricable links with the politics of difference based on the stigmatisation and criminalisation of different segments of society, particularly oppositional political parties, groups, movements, and organisations.

In Turkey also, the AKP has used the motto of 'homegrown and national' (yerli ve milli) and invested in 'traditional morality'. This includes the extensive use of Islamist, conservative, corporatist, patriarchal, and national discourses to reproduce its hegemony, consolidate the partisanship among the voter base, and legitimise its undemocratic practices (Bilgiç, 2018; Coşar \& Yeğenoğlu, 2011, pp. 555-556; see also 
Babacan et al., 2021; Çarkoğlu, 2007; 2020Geniş, 2020; Özkızıltan, 2019; Taşkın, 2013; Yarar, for a detailed discussion on the AKP's Islamist and/or conservative character). With this, the AKP has been able to forge violent forms of accumulation with political authoritarianism. As the AKP consolidated its power, dissenting groups were quickly stigmatised and criminalised under the category of 'the enemy' who posed a threat to the security of the nation (Arslanalp \& Erkmen, 2020, p. 949; see also Akça, 2014; Tuğal, 2016). This stigmatisation and criminalisation operates through social categories of difference to marginalise dissenting groups such as Kurds, Alevis, women, and LGBTI+. These groups are targeted not only by governmental and non-governmental institutions (such as NGOs, labour unions, and media outlets) but also subjected to coercion through increased prosecution and police violence (Adaman \& Akbulut, 2020, p. 5; see also Porta \& Atak, 2015; Kaygusuz, 2018). Furthermore, those who are stigmatised and criminalised are also taken under an 'authoritarian surveillant assemblage' whereby the state suppresses dissent through surveillance (Topak, 2019).

Within this context, the introduction of Specially Authorised Courts (2004), amendments in the Penal Code (2005), the Criminal Procedure Code (2005), the Counterterrorism Law (2006), and the Police Powers and Duties Law (2007) have expanded the definition of 'terrorism' and formulated new powers for the courts and prosecutors (Babacan et al., 2021; Özden et al., 2017). According to the Council of Europe, Turkey has the highest incarceration rate among its member states, with 357 inmates per 100,000 inhabitants (Aebi \& Tiago, 2021). Together with the emergency and presidential decrees, those amendments increased the arbitrary implementation of security laws and facilitated stigmatisation and criminalisation against oppositional forces to justify coercion and co-optation policies.

As Özen and Körükmez show in Chapter 8, the Academics for Peace who challenged the state's repressive policies in Kurdish regions are targeted by President Erdoğan as 'dark', 'supporters of terrorism', and 'colonial intellectuals'. The Academics for Peace were put on trial on charges of terrorist propaganda, purged from their positions, or forced to retire, and subjected to civil death for signing a peace petition to show their opposition to the intensive state violence in the aftermath of the peace process that led to hundreds of civilians death. 
Gezi protesters were denounced as çapulcular (thugs, drifters, vagabonds), 'Kemalists', 'elites', 'international interest lobbies', 'feminists', and 'homosexuals', which also discursively targeted the crosscoalitional and intersectional nature of the Gezi protests. These polarising discourses permeate into the micro-spaces of social struggles. For example, Yabanc1 in Chapter 10 explains how the solidarity of Muslim Left Movement with workers who were dismissed for joining in a leftwing trade union was denounced by the employers as 'communists, terrorist, and anarchists'. Moreover, denouncing civil society organisations with 'Soros', 'foreign countries', and 'German foundations' aimed to stigmatise them and shrink the already limited civil space (Kaya \& Öğünç, 2020).

The extant research on urban transformations in Turkey demonstrates how urban transformation projects were promoted with corporatist and nationalist discourses to justify and facilitate the displacement and dispossession of the urban poor, including marginalised ethnic and religious communities like Kurds, Alevis, and Roma (Borsuk \& Eroglu, 2020; Cavusoglu \& Strutz, 2014; Lovering \& Turkmen, 2011; Turkun, 2011). For instance, Lovering and Turkmen (2011, p. 84) put forward that Kurdish identity has been a factor that 'gave the authorities added leverage' for exploiting racism and the tendency to equate Kurdishness with 'political disloyalty, quasi-feudal primitivism, general anti-social attitudes, and criminality'. In Chapter 7, Murat demonstrates how a neighbourhood inhabited by left-leaning Alevis was kept under strict state surveillance and violence, particularly since the 2013 Gezi protests. The criminalisation of residents with charges of terrorism was also an important factor in the top-down imposition of the urban transformation project in Sur, as demonstrated by Taş in Chapter 4 .

\section{Contesting Authoritarian Neoliberalism}

Authoritarian neoliberal policies in Turkey have set in motion a series of resident-driven and community-based mobilisations and social movement activism. We demonstrate below how authoritarian neoliberalism is contested through (1) strikes, (2) protests and demonstrations, (3) petitions and network building, (4) litigation, (5) everyday struggles, as well as (6) armed acts of contention. These acts of resistance can be used concurrently by people to articulate claims and grievances. Needless to say, the emergence and evolution of contestation is connected with a 
broader regime environment that we have elaborated on in the previous section through the intertwined mechanisms of executive centralisation, autocratic legalism, cronyism, dispossession, criminalisation, and stigmatisation. In this respect, this section specifically focuses on how acts of resistance are employed by people in response to the authoritarian implementation of neoliberal politics in Turkey.

\section{Strike}

With Labour Act no. 4857, which was accepted under the AKP government in 2003, pro-labour practices and institutions were modified or abolished, causing significant deterioration of workers' rights (Çelik, 2015). The authoritarian neoliberal policies of the AKP not on2019ly made the labour market more competitive, precarious, and de-unionised, but also prevented workers' strikes by the threat of police violence towards workers (Erol, 2019). The alcohol and tobacco products company TEKEL was among the privatised companies under the AKP. In the first stage of privatisation in 2003 , the buyer was a national consortium, while in the second stage in 2008 the buyer was foreign capital, namely British American Tobacco. The post-privatisation settlement saw the removal of 12,000 TEKEL workers from their jobs and changing the working conditions of remaining workers via enactment of a new regulation (4-C) under the Labour Act of Turkey (Law no. 4857). It led to significant labour resistance in 2009 (Türkmen, 2012), which also attracted sympathy from the public (Önis, 2011, p. 721). Similarly, the large-scale strikes of the United Metal Workers Union in 2015 were referred to as the 'Metal Storm' by the media (Kivilcım, 2021, p. 198).

Although the AKP inherited a neoliberal system with legal constraints set by the military regime in the 1980s, ${ }^{9}$ the AKP government further entrenched neoliberal policies to put pressure on the workers (Yalman \& Topal, 2019, p. 459). With Law no. 6356 on trade unions and collective bargaining in 2010, the Council of Ministers was given the authority and power to 'suspend strikes and lockouts for reasons of national security and public health' (Bozkurt-Güngen, 2018). According to the report of Türkiye Devrimci Isşci Sendikaları Konfederasyonu (Confederation of Revolutionary Trade Unions of Turkey, DİSK) in 2020, a total of 17 strikes were 'postponed', practically meaning banned under AKP rule (see Erol, 2019). Among these 17 strikes, 12 were banned after Law no. 6356 was passed in 2010. Seven of these 12 strikes were banned under the state 
of emergency between 2016 and 2018, and two were banned with presidential decrees in 2019 and 2020, affecting more than 194,000 workers (DİSKAR, 2020).

In addition to state policies banning strikes, Yalman and Topal (2019) put forward two factors to explain why resistance against privatisation failed to develop a counter-hegemonic strategy: informalisation into state employment and the labour containment strategy of the AKP through unions close to the AKP. This was also related to the mainstream media, which did not fully cover the resistance or the police brutality towards the resisting workers but instead sought to 'overwhelmingly reflect the opinions of public authority figures' (Dogu, 2015, p. 643). The subservience of the mainstream media underlines the interaction between authoritarianism and neoliberalism in Turkey and the media moguls' desire to establish a good relationship with the government. In the meantime, Isşi Sağlığr ve İş Güvenliği Meclisi (Workers' Health and Work Safety Assembly, ISIG) reports reveal that thousands of workers have died in 'work accidents' (also referred to as work-related murders) since the AKP came to power in 2002. ${ }^{10}$ Studies also show how the erosion of pro-labour rights and institutions enables and hides the deepening exploitation of women, ethnic communities, and migrants in overlapping and intersecting ways. While Kurds (Alpman, 2016) and women (Alnıaçı et al., 2017; Saraçoğlu et al., 2018; Uyar Mura, 2021) are among the disadvantaged groups whose labour force are subjected to exploitation and precarisation, migrants (predominantly Syrians and Afghans) and children are among those who suffer from lack of labour health and safety measures in workplaces. The majority of workplace deaths occur in the sectors of agriculture/forestry and construction.

The number of strikes has dropped significantly under the AKP government when compared to earlier periods (Bozkurt-Güngen, 2018, see also Bekmen et al., 2020). This goes hand in hand with the decreasing unionisation, and disorganisation of labour. Based on the Work-Related Murders Report in 2020 , only $4 \%$ of the deceased workers belonged to a union, whereas the remaining 96\% were non-unionised (İş Cinayetleri Raporu, 2020). Özkiziltan (2019, pp. 7-8) notes that under the AKP rule, 'the trade union density has dropped by almost $50 \%$, the percentage of workers whose wages and working conditions are regulated by a collective agreement has decreased more than threefold'. While pro-AKP unions (i.e., HAK-İŞ and TÜRK-İŞ) were largely uncritical of the worsening conditions of workers in Turkey, the unions that were not under the AKP's 
hegemony/guidance (i.e., DİSK) continued to voice their discontent and resisted the AKP's policies with strikes as well as protests and demonstrations. According to Arslanalp and Erkmen (2020), a total of 20 labour-related protests were banned in Turkey between 2007 and July 2016.

\section{Protest and Demonstration}

Labour-related protests were not the only types of protests that were banned under the AKP. Arslanalp and Erkmen (2020, p. 99) argue that protest repression was already embedded in the authoritarian politicalinstitutional context of Turkey'. The authoritarian implementation of neoliberal policies gave way to new geographies of protest, some of which also incorporated new methods and practices of contention such as protest camping, on-site guarding (nöbet), occupation, and do-it-yourself (DIY) media production. Some examples of grassroots mobilisations against the consequences of authoritarian neoliberal policies include the protests against gold-mining in Bergama (Çoban, 2004) and Mount İda (Avc1, 2017), worker's protests after the mining disaster in Soma (Adaman et al., 2019; Çelik, 2017), resistance against privatised hydropower development (Aksu et al., 2016; Kavak, 2020), and squatter-based mobilisations against urban development projects in various parts of Turkey (Kuyucu \& Unsal, 2010). The contributions in this volume also illustrate grassroots collective mobilisations like villagers' protests against the land enclosure of the Greenhouse agro-business investment (Chapter 3), squatter dwellers' objections against the urban transformation project in Sur (Chapter 4), and community mobilisation against the hydropower plant projects in the Karakoçan district of Elazı ̆ (Chapter 6).

The Gezi protests in 2013 were a landmark illustrating how a grassroots urban and environmental mobilisation can scale up to the national and even global arena, bridging environmental concerns, claims for democracy, human rights, and economic grievances and challenging the authoritarian, conservative, and neoliberal policies of the AKP government. They were an example of radical democracy, including prefigurative and horizontal networks of solidarity, as protesters re-appropriated public space through public forums held in open spaces, popular assemblies, and digital activism (Akça et al., 2014; Bilgiç, 2018; David \& Toktamış, 2015; Korkut \& Sarfati, 2020; Kuymulu, 2013; Yörük, 2014). They have also given way to a new form of activism and politics of emotion as people 
started to talk about the Gezi 'spirit', referring to politics of solidarity and building of cross-class and intersectional coalitions against hegemonic AKP policies. The Taksim Solidarity Platform, an agglomeration of neighbourhood associations, professional chambers, local community organisations, and university students, guarded the trees at Gezi Park through contentious activities, such as organising common breakfasts, petition campaigns, demonstrations, and the organisation of vigils. As the state responded to protesters with police brutality, the movement triggered nationwide protests with repercussions in the diaspora, and gathered together a diverse coalition including LGBTI+, Anti-Capitalist Muslims, feminists, and football fans.

In Chapter 9, Özdüzen examines Gezi's legacy in Turkey through the concepts of the creative rebel city, media production, and cultural activism. While Gezi brought inexperienced activists together and endowed them with a sense of solidarity and empowerment against the authoritarian, conservative, and neoliberal policies of the AKP, it also helped them experiment with new activism through DIY media production, media texts (e.g., images, videos, and podcasts) produced by amateur or semi-professional users and/or audiences. She outlines how new social movements and actors that contest the AKP's policies, like anti-capitalist Muslims, Northern Forests Defense, the Emek Movement, Gezi Radyo, and Karşı Radyo, actively appropriate both physical and online/offline spaces. As detailed by Özdüzen, this points out the creativity, community-making, and intersectionality in the recent protest movement and their connections with global protests movements like the Arab Spring and Occupy. Although government repression of social movements limits their activities and pushes them to act anonymously, their multifaceted use of media technologies helps them use both physical and online spaces to organise and protest in novel and innovative ways.

\section{Petition and Network Building}

Petitions through which individuals and groups address officials with written requests is a common form of claim-making in Turkey. Both grassroots struggles and social movements occasionally organise petition campaigns collecting people's signatures to support their claims. A significant example of such claim-making is given by Özen and Körükmez in Chapter 8 through the Academics for Peace case, who organised a petition 
among academics to contest the AKP's authoritarian and violent practices in Kurdish regions. Following dismissals and human rights violations against petitionary academics, Academics for Peace developed into a platform and established several networks in which academics from different backgrounds gathered and mobilised under alternative academies, global networks, and legal struggles. These platforms also functioned as solidarity networks, establishing national and global connections with legal teams and international organisations to provide legal counselling and occasionally financial support.

In Chapter 7, Murat focuses on primary education under authoritarian neoliberalism through a case study of People's House Summer Schools, which organise an anti-neoliberal campaign for 'free, scientific, and equal in mother tongue education' with bottom-up, volunteer-based, solidarity activities in a left-leaning Alevi-majority neighbourhood. Murat's ethnographic fieldwork reveals that while the Gezi protests and increasing police violence in the aftermath of the protests resulted in a record number of volunteer teachers, the number of students dropping out due to the security concerns of parents in the neighbourhood also increased. In some collective mobilisations like in Sur (Chapter 4) and Elazığ (Chapter 6), we also see the crisscrossing alliances/networks of solidarity between residents and civil society actors.

Yabanc1's analysis of the Muslim Left Movement in Chapter 10 complements Özdüzen's analysis as she also details Gezi's legacy for social movements. Yabanc1 points to the dilemma of neoliberal and authoritarian pressure, as it also re-politicises civil society as oppositional groups turn to civil society due to their limited access to institutionalised politics through political parties. Anti-capitalist Muslims are reorganised in the Muslim Left movement using grassroots resistance and solidarity as acts of contention. The Muslim Left movement identifies as a platform that privileges off-stage contention, charity, and deliberation. Their contentious repertoire is also novel and innovative as they organise fraternity iftars (breaking fast during Ramadan), called yeryüzü sofralar, as an alternative to the government-organised iftars that are criticised for being expensive meals with a show-off of religiosity for the conservative uppermiddle class. These fraternity iftars are also occasions that give voice to the marginalised, like subcontracted workers, victims of occupational accidents, street waste-pickers, homeless people, refugees and migrants, and women at shelters. Muslim left activism also engages in solidarity acts with workers by organising seminars, demonstrations, and protests. 
This solidarity with the working classes, including their involvement on May 1 , signals the potential of new cross-class coalitions between social movements and working classes.

Although not covered in this volume, some of the strongest reactions to the AKP's authoritarian neoliberalism and promotion of gendered and patriarchal state have come from feminists and LGBTI+. Neoliberal policies implemented by the AKP brought about the convergence of market-oriented policies with gendered and patriarchal policies. Development projects that affect urban, environmental, and rural areas enabled gendered dispossessions and amplified gendered and intersectional inequalities (see Borsuk, 2021; Erman \& Hatiboğlu, 2017). Feminist organisations have launched a series of campaigns for equal pay for equal work, state-sponsored child care, anti-femicide, and LGBTI+ rights campaigns. They have built solidarity networks with the LGBTI+, bar associations, and local organisations, organising protests, demonstrations, and litigation. These campaigns have also been supported by national and international actors (the EU in particular). However, as the AKP consolidated authoritarian neoliberalism through conservative, gendered, and patriarchal discourses, it also engaged in sidelining established women's organisations by setting up GONGOs that act as supporters of the government in the domains of women and family (Negrón-Gonzales, 2016, Yarar, 2020; see also Chapter 10 in this volume).

\section{Litigation}

A major contention strategy adopted against authoritarian neoliberalism is litigation processes. Chapters 3 and 6 show how companies engage in implementing projects without waiting for the results of court processes. In Chapter 6, Kutlu focuses on the litigation of Karakoçan residents against a hydropower plant. When the courts decided against the plaintiffs or dismissed other court decisions that ordered pausing the construction of hydropower plants, local people compromised with what they were offered. Kutlu demonstrates that there are limitations to the capacity of people to initiate and sustain the court process due to fees and temporal limitations. Different from the neoliberal mindset of government, the judiciary adopts a relatively more liberal perspective attempting to strike a balance between the individual's right to property and developmental policies. Nonetheless, due to the shortcomings of liberal human rights paradigm, it falls short of showing regard for cultural and ecological 
concerns. In Chapter 3, Eren shows that in the case of the Greenhouse agro-business investment, grassroots resistance could not halt the project due to the co-optation and containment strategies that stemmed from the security forces' intervention against the protesting villagers, the co-optation of local leaders, and inefficient litigation processes.

In addition to solidarity networks of the Academics for Peace (as discussed in detail by Özen and Körükmez in Chapter 8), academics who have been stripped of their basic rights also use litigation as a resistance strategy. There have been some cases where dismissed academics have opened court cases for reemployment or applied to the State of Emergency Commission demanding to be returned to their positions.

Although litigation is still used as a mechanism of resistance, the capacity of legal system to respond to people's grievances is also undermined by the AKP government that implemented new measures to curtail bar associations' oppositional voice. In 2020, a draft law was introduced to allow multiple bar associations to be established in every province in Turkey. The introduction of multiple bars was yet another policy for diluting the bar's oppositional voice against the use and abuse of law in Turkey. In response to this draft law, thousands of lawyers organised protests and marched to Turkey's capital, Ankara. Slogans such as 'Defence cannot be silenced' and 'Everybody needs justice' were used by the protesters. In response to this contention, there were governorimposed demonstration bans, and resisting lawyers were subject to police brutality. Despite the protests, the bill was eventually passed in July 2020 , deepening the damage to judicial independence. This is likely to have repercussions on people's capacity to oppose authoritarian neoliberalism in Turkey, hindering the right to defence as well as the building of networks between people and bar associations to resist these policies.

\section{Everyday Struggles}

Resistance against authoritarian neoliberalism happens not only through acts of contention that are visible, such as protests, strikes, demonstrations, or litigation but also through everyday acts of survival. In Chapter 3, Eren reveals how the entanglement of the authoritarian state with neoliberalisation enables and enhances patriarchal relations in the workplace, accentuating the exploitation of women's labour. Women who work in the agro-business company feel empowered, as they can provide for themselves and their children through their work. But their 
labour is doubly exploited as compared to men as they also engage in tasks that men abstain from in the workplace, as these tasks are seen as an extension of women's patriarchal role at home. While the company imposes disciplining strategies like high performance and speed, women also engage in everyday struggles to protect the slowest workers and object to dire working conditions. However, these strategies remain at the everyday level with limited unionisation and collective bargaining capacity of workers.

In Chapter 4, Taş explores how the commodification of housing under the heavy-handed state repression magnifies inequalities in society, deepening the precarisation of the Kurdish urban poor and severely deteriorating their means for survival. Residents' everyday struggles to stay in their neighbourhood can be seen as their disruption of authoritarian forms of racial capitalism that marginalise residents based on their Kurdish identity. Murat's case study in Chapter 7 showcases how increased police surveillance and repression affect students' feelings and experiences in the classroom, which is visible in their drawings. Chapter 7 also shows how authoritarianism reflects upon marginalised children, fuelling their politicisation into oppositional movements at a younger age in marked contrast to the regime's aim for cultural hegemony, raising conservative and compliant youth through education.

\section{Armed Acts of Contention}

Vigilantism in response to authoritarian neoliberal policies in different contexts is an area that needs to be further investigated. Cases from the Zapatistas in Mexico to the Revolutionary Armed Forces of Colombia show that armed acts of contention have been used in response to neoliberalism. Although it is not covered as one of the case studies in this volume, we see armed acts of contention in response to authoritarian neoliberalism as a rare, yet available form of action. Armed acts against the authoritarian neoliberal policies in Turkey is conducted by already-existing insurgent groups, which were not established specifically to fight against authoritarian neoliberalism. Nonetheless, these existing movements, such as the Partîya Karkerên Kurdistanê (Kurdistan Workers Party, PKK) have been conducting activities in their stronghold regions (i.e., Adiyaman, Bingöl, Dersim, Siirt, Şırnak). These activities include hijacking vehicles used in the construction of hydropower plans or military fortresses, kidnapping or at times killing their drivers, and burning the goods these 
vehicles carried (Anadolu Ajansı, 2017; Canlı Haber, 2015; Cumhuriyet, 2014; DoğruHaber, 2014; EnSonHaber, 2015; Hürriyet, 2017). We view such armed acts of contention as responses to authoritarian neoliberalism for two reasons. First, these projects are contracted to the private construction companies, which are in close economic ties with the AKP. Second, the construction of dams and military fortresses in the Kurdishdominated cities of Turkey are viewed to be colonial acts of the state (Cudi, 2020) that aim for demographic change in the region, as well as surveillance and displacement of its inhabitants. It should be added that the construction of these sites also means the limitation of the capacity of the armed groups in the region, which may be another motivation behind their actions.

\section{CONCluding Remarks}

In this chapter, we analysed the dynamic interaction between authoritarian neoliberalism and its contestation. We have argued that authoritarian neoliberalism in Turkey is consolidated through (1) executive centralisation; (2) autocratic legalism, enabling the arbitrary and coercive implementation of neoliberal policies; (3) violence-fuelled rentier accumulation; and its (4) crony distribution, which is used to extract economic value through privatisation, commodification, and marketisation; and (5) the stigmatisation and criminalisation of popular opposition, which underpins the accumulation process to legitimise the authoritarian implementation of neoliberal policies and disempower popular discontent.

We have also demonstrated that the domination of authoritarian neoliberal policies is challenged by grassroots and social movement mobilisations that contest and disrupt market policies through various acts of resistance, such as strikes, protests, demonstrations, petitions, network building, and litigation. People also engage in everyday acts of resistance to undermine the exploitative capitalist relations promoted by the authoritarian state, like in their daily struggle to continue living in their demolished neighbourhoods against authoritarian urban transformation projects, or slowing down work to protect their fellow workers. Albeit few and limited in number, we have also shown that existing insurgent armed groups have been conducting acts of contention to disrupt authoritarian neoliberal policies of the state, primarily the construction of hydropower plants in the Kurdish-dominated cities of Turkey. Although these acts of resistance do not proclaim a politics of rebellion against authoritarian 
neoliberal states, it is possible to observe new forms of dissent and resistance that run counter to the individualistic, consumerist, and apolitical subjectivity and practices promoted by neoliberal politics (Brown, 2015). We believe that understanding resistance is crucial to understand how grassroots struggles and movements, in some cases, jump in scale and grow exponentially, setting up cross-class alliances and broader campaigns with the ability to challenge national politics.

In this chapter, we have shown the dynamic relationship between the consolidation and contestation of authoritarian neoliberalism in Turkey. We define this relationship as contentious interaction. While the state applies various mechanisms to consolidate authoritarian neoliberalism, it continues to be challenged with various acts of resistance. Hence, what we see is not a unidirectional process, but a dynamic relationship between these mechanisms that shape each other. We have not discussed the containment strategies of resistance under a separate heading, since we see it as an internal part of the dynamic interaction between consolidation and contestation of authoritarian neoliberalism.

This extensive chapter has aimed to build a general framework about the consolidation, contestation, and containment of authoritarian neoliberalism by mainly building on the case studies presented in this book. We have underlined some key examples to illustrate the mechanisms of consolidation and resistance. Many other examples of authoritarian neoliberalism may be analysed through this framework, which captures the complexity of the contentious interaction. In the remaining chapters of this volume, the contributors go into details of specific subject areas (i.e., urban transformation, agriculture, education, media, environment, civil society), which we believe to be significant case studies that show a wide array of policies and struggles that can be analysed within the framework we propose.

\section{Notes}

1. By racial impacts, we refer to racialisation processes, which Omi and Winant describe as 'the extension of racial meaning to a previously racially unclassified social relationship, social practice or group' (2014, p. 111). Racialisation intersects with social, political, and economic processes that assign certain immutable characteristics and differences to people and their social situations. For example, economic racialisation identifies certain groups as 'undeserving', 'dirty', or 'dangerous' and serves to justify their exploitation and exclusion from the economic market and fair distribution (Gans, 2017, p. 343). 
2. The 1980 coup d'état is considered as a milestone in Turkey's economic transformation towards neoliberal political economy. It paved the way for the implementation of the January 24 Decisions the Adalet Partisi (Justice Party, AP) declared in 1980, less than a year before the military coup. These decisions, which implicated structural adjustment measures to privatise state-led enterprises and open the Turkish economy to global markets, met strong opposition from the left-wing opposition within the parliament as well as society. Following the coup, the heavy-handed repression of the military junta against political actors and social movements and the suppression of civil rights and freedoms in Turkey did not 'leave much scope for opposition to the new politico-economic model' (Önder, 1998, p. 50, also see Önder, 2016).

3. Between 2014 and 2017, while the Presidency was still largely a ceremonial post, Recep Tayyip Erdoğan acted as the de facto Head of Government (for a further discussion, see Sayar1, 2016; Sözen, 2019).

4. See Clua-Losada and Ribera-Almondoz (2017) for a similar discussion on Spain.

5. A reflection of this attitude can also be observed in the AKP's foreign policy. The foreign policy doctrine of 'Blue Homeland' (Mavi Vatan), which introduces new norms favouring Turkey's claims in the Eastern Mediterranean, had been promoted by the AKP.

6. Moreover, comparing the cases of Hungary, Venezuela, and Ecuador, Scheppele (2018) argues that an important step of autocratic legalism is 're-writing the constitution', which has been on the agenda of the AKP for years.

7. The policies that have been used to neoliberalise the economy in the 1980s and 1990s (such as decentralisation of state administration, privatisation of state enterprises, and land reforms) were used to generate and redistribute rents between different groups, building new patronage networks between policy makers, private sector, and society. In bureaucracy, as state employment was no longer a channel of upward mobility either socially or economically, everyday forms of resistance such as working less efficiently or taking bribes at the bureaucratic level began (Önder, 1998, p. 67). The commodification of land was used to distribute rents and gain support from discontented citizens from the urban poor who lived in squatter settlements. The financialisation of the economy led to new entanglements between the state and private sector that blew up, particularly with banking scandals and financial crises that resulted in the economic crisis of 2001. For further information on neoliberalisation in Turkey, see Yeldan (2016), Boratav and Yeldan (2006), and Özbay et al. (2016).

8. In Turkey, there are public and foundation universities. Foundation universities are established by foundations and are non-profit. However, 
most of the foundations that establish universities are linked to the business people. The foundation universities have to provide scholarships to a certain number of students as dictated by law but the rest of the students pay tuition fees, unlike in public universities.

9. In the 1980s, left-wing politics and movements (e.g., the centre-left SHP [Social Democratic Populist Party, Sosyal Demokrat Halkçı Parti]) were still influential and able to gather electoral support. The re-establishment of trade unions led to general strikes in the 1990s. The leftist movements worked for the improvement of workers' rights as well as democracy, human rights, and freedoms (Önder, 1998, p. 67). Privatisation was another issue which was responded with resistance upheld not only by leftists and labour unions, but also by ultra-nationalist parties and statist groups within the state bureaucracy, such as the high courts (i.e., the Constitutional Court, the Council of State) (Önder, 1998, 2016; Önis, 2011).

10. These reports are available at: http://isigmeclisi.org/is-cinayetleri-rap orlari.

\section{REFERENCES}

Adaman, F., \& Akbulut, B. (2020). Erdoğan's three-pillared neoliberalism: Authoritarianism, populism and developmentalism. Geoforum.

Adaman, F., Arsel, M., \& Akbulut, B. (2019). Neoliberal developmentalism, authoritarian populism, and extractivism in the countryside: The Soma mining disaster in Turkey. The Journal of Peasant Studies, 46(3), 514-536.

Aebi, M. F., \& Tiago, M. M. (2021). SPACE I-2020-Council of Europe annual penal statistics: Prison populations. Council of Europe. Available at: https://wp.unil.ch/space/files/2021/04/210330_FinalReport_SPACE_ I_2020.pdf.

Akça, İ. (2014). Hegemonic projects in post-1980 Turkey and the changing forms of authoritarianism. In I. Akça, A. Bekmen, \& B. A. Özden (Eds.), Turkey reframed: Constituting neoliberal hegemony (pp. 13-46). Pluto Press.

Akça, I., Algül, S., Dincer, H., Keleşoglu, E., \& Özden, B. A. (2018). When the state of emergency becomes the norm: the impact of executive degrees on Turkish legislation. Heinrich Böll Stiftung. Available at: https://olaganlasanohal.com/ files/when_the_state_of_emergency_becomes_the_norm.pdf.

Akça, I., Bekmen, A., \& Özden, B. (Eds.). (2014). Turkey reframed: Constituting neoliberal hegemony. London: Pluto Press.

Akçay, Ü. (2018). Neoliberal populism in Turkey and its crisis (Working Paper, No. 100/2018). Hochschule für Wirtschaft und Recht Berlin, Institute for International Political Economy (IPE). 
Akkoyunlu, K., \& Öktem, K. (2016). Existential insecurity and the making of a weak authoritarian regime in Turkey. Southeast European and Black Sea Studies, 16(4), 505-527.

Aksoy, A. (2012). Riding the storm: 'New Istanbul'. City, 16(1-2), 93-111.

Aksu, C., Erensü, S., \& Evren, E. (Eds.). (2016). Sudan Sebepler: Türkiye'de Neoliberal Su-Enerji Politikaları ve Direnişleri. İletişim Yayınları.

Alnıçık, A., Altan-Olcay, O., Deniz, C., \& Gökşen, F. (2017). Gender policy architecture in Turkey: Localizing transnational discourses of women's employment. Social Politics: International Studies in Gender, State \& Society, 24(3), 298-323.

Alpman, P. S. (2016). Esmer Yakahlar: Kent-Sinf-Kimlik ve Kürt Emeği. İletişim Yayınları.

Anadolu Ajansı. (2017, August 30). Teröristler İs Makinelerini Yaktı. Available at: https://www.aa.com.tr/tr/turkiye/teroristler-is-makinelerini-yakti/896684.

Arslanalp, M., \& Erkmen, D. T. (2020). Mobile emergency rule in Turkey: Legal repression of protests during authoritarian transformation. Democratization, 27(6), 947-969.

Atasoy, Y. (2020). Neoliberalism and the rise of authoritarianism in Turkey under AKP. In B. Berberoglu (Ed.), The global rise of authoritarianism in the 21st century: Crisis of neoliberal globalization and the nationalist response (pp. 197217). Routledge.

Avc1, D. (2017). Mining conflicts and transformative politics: A comparison of Intag (Ecuador) and Mount Ida (Turkey) environmental struggles. Geoforum, $84,316-325$.

Aytaç, S. E., \& Öniş, Z. (2014). Varieties of populism in a changing global context: The divergent paths of Erdoğan and Kirchnerismo. Comparative Politics, 47(1), 41-59.

Babacan, E., Kutun, M., Pinar, E., \& Yilmaz, Z. (2021). Introduction-debating regime transformation in Turkey: Myths, critiques and challenges. In E. Babacan, M. Kutun, E. Pinar, \& Z. Yilmaz (Eds.), Regime change in Turkey: Neoliberal authoritarianism, Islamism and hegemony (pp. 1-12). Routledge.

Bailey, D., Huke, N., Lewis, P., \& Shibata, S. (2021). Variegated anti-austerity: Exploring the demise and rise of class struggle during the crisis of neoliberalism. Social Policy and Society, 20(1), 158-171.

Bakıner, O. (2017). How did we get here? Turkey's slow shift to authoritarianism. In B. Başer \& A. E. Öztürk (Eds.), Authoritarian politics in Turkey: Elections, resistance and the AKP (pp. 21-46). I.B. Tauris.

Başer, B., \& Öztürk, A. E. (2017). Authoritarian politics in Turkey: Elections, resistance and the AKP. I.B. Tauris.

Bastia, T., \& Bressán, J. M. (2018). Between a guest and an okupa: Migration and the making of insurgent citizenship in Buenos Aires' informal settlements. Environment and Planning A: Economy and Space, 50(1), 31-50. 
Bayat, A. (2000). From 'dangerous classes' to 'quiet rebels': Politics of the urban subaltern in the global south. International Sociology, 15(3), 533-557.

Bedirhanoğlu, P. (2021). Global class constitutions of the AKP's 'authoritarian turn' by neoliberal financialization. In E. Babacan, M. Kutun, E. Pinar, \& Z. Yilmaz (Eds.), Regime change in Turkey: Neoliberal authoritarianism, Islamism and hegemony (pp. 68-84). Routledge.

Bekmen, A., Öngel, F. S., \& Hadiz, V. R. (2020). Contesting working-class politics in Turkey: Social transformations, Islam, and the left. Critical Sociology, 46(7-8), 1025-1040.

Bermeo, N. (2016). On democratic backsliding. Journal of Democracy, 27(1), 5-19.

Bhatia, S., \& Priya, K. R. (2018). Decolonizing culture: Euro-American psychology and the shaping of neoliberal selves in India. Theory \& Psychology, $28(5), 645-668$.

Bilgiç, A. (2018). Reclaiming the national will: Resilience of Turkish authoritarian neoliberalism after Gezi. South European Society and Politics, 23(2), 259-280.

Birch, K. (2015). Neoliberalism: The whys and wherefores... and future directions. Sociology Compass, 9(7), 571-584.

Birch, K. (2017). A research agenda for neoliberalism. Edward Elgar.

Boratav, K. (2013, June 22). Korkut Boratav, Gezi Direnişini değerlendirdi': Olgunlaşmış bir sımfsal başkaldır [Korkut Boratav evaluated the gezi resistance: A matured class revolt]. Sendika.org. www.sendika.org/2013/06/ her-yer-taksim-her-yer-direnis-bu-isci-sinifinin-tarihsel-ozlemi-olan-sinirsiz-dol aysiz-demokrasi-cagrisidir-korkut-boratav/.

Boratav, K. (2016). The Turkish bourgeoisie under neoliberalism. Research and Policy on Turkey, 1(1), 1-10.

Boratav, K., \& Yeldan, E. (2006). Turkey, 1980-2000: Financial liberalization, macroeconomic (in)-stability, and patterns of distribution. In L. Taylor (Ed.). External Liberalization in Asia, Post-Socialist Europe, and Brazil, (pp. 417455). Oxford Scholarship Online.

Borsuk, I. (2017). Public sector integrity. In A. Sonmez, I. Borsuk, \& Y. Hatipoglu. Business integrity country agenda-Turkey. Transparency International Publications. ISBN: 978-605-82771-2-0.

Borsuk, I. (2021). Gendered dispossession and women's changing poverty from squatter settlement into mass housing: A case study from Turkey. Environment and Planning A: Economy and Space. https://doi.org/10.1177/0308518X2 11016864.

Borsuk, I., \& Eroglu, E. (2020). Displacement and asset transformation from inner-city squatter settlement into peripheral mass housing. European Urban and Regional Studies, 27(2), 142-155. 
Bozkurt, U. (2013). Neoliberalism with a human face: Making sense of the Justice and Development Party's neoliberal populism in Turkey. Science of Society, $77(3), 372-396$.

Bozkurt-Güngen, S. (2018). Labour and authoritarian neoliberalism: Changes and continuities under the AKP governments in Turkey. South European Society and Politics, 23(2), 219-238.

Brown, W. (2015). Undoing the demos: Neoliberalism's stealth revolution. Zone Books.

Brown, W. (2019). In the ruins of neoliberalism: The rise of antidemocratic politics in the West. Columbia University Press.

Bruff, I. (2014). The rise of authoritarian neoliberalism. Rethinking Marxism, 26(1), 113-129.

Bruff, I. (2016). Neoliberalism and authoritarianism. In S. Springer, K. Birch, \& J. MacLeavy (Eds.), Handbook of neoliberalism (pp. 107-117). Routledge Taylor \& Francis Group.

Bruff, I., \& Tansel, C. B. (2019). Authoritarian neoliberalism: Trajectories of knowledge production and praxis. Globalizations, 16(3), 233-244.

Bruff, I., \& Wöhl, S. (2016). Constitutionalizing austerity, disciplining the household. In A. A. Hozic \& J. True (Eds.), Scandalous economics: Gender and the politics of financial crises (pp. 92-108). Oxford University Press.

Buğra, A., \& Candaş, A. (2011). Change and continuity under an eclectic social security regime: The case of Turkey. Middle Eastern Studies, 47(3), 515-528. https://doi.org/10.1080/00263206.2011.565145.

Buğra, A., \& Keyder, Ç. (2006). The Turkish welfare regime in transformation. Journal of European Social Policy, 16(3), 211-228. https://doi.org/10. $1177 / 0958928706065593$.

Canlı Haber. (2015, July 21). PKK Silopi'de Iss Makinesi Yaktı! 2 Isşi Kayıp. Available at: https://www.canlihaber.com/haber/5295874/pkk-silopide-ismakinesi-yakti-2-isci-kayip.

Çarkoğlu, A. (2007). A new electoral victory for the 'Pro-Islamists' or the 'New Centre-Right'? The Justice and Development Party phenomenon in the July 2007 parliamentary elections in Turkey. South European Society and Politics, 12(4), 501-519.

Casolo, J., \& Doshi, S. (2013). Domesticated dispossessions? Towards a transnational feminist geopolitics of development. Geopolitics, 18(4), 800-834.

Castaldo, A. (2018). Populism and competitive authoritarianism in Turkey. Southeast European and Black Sea Studies, 18(4), 467-487.

Cavusoglu, E., \& Strutz, J. (2014). Producing force and consent: Urban transformation and corporatism in Turkey. City, 18(2), 134-148.

Çelik, A. (2015). Turkey's new labour regime under the Justice and Development Party in the first decade of the twenty-first century: Authoritarian flexibilization. Middle Eastern Studies, 51(4), 618-635. 
Çelik, C. (2017). Kırsal Dönüşüm ve Metalaşan Yaşamlar: Soma Havzası'nda İşçileşme Süreçleri ve Sınıf İlişkileri. Praksis, 43 (1), 785-810.

Chacko, P. (2018). The right turn in India: Authoritarianism, populism and neoliberalisation. Journal of Contemporary Asia, 48(4), 541-565.

Chatterjee, P. (2004). The politics of the governed: Reflections on popular politics in most of the world. Columbia University Press.

Çı̆̆g, E. Ç., \& Çı̆̆g, Ü. (2021). Transformation of news media. In E. Babacan, M. Kutun, E. Pinar, Z. Yilmaz (Eds.) Regime change in Turkey: Neoliberal authoritarianism, islamism and hegemony (pp. 85-102). Routledge.

Clua-Losada, M. \& Ribera-Almandoz, O. (2017). Authoritarian neoliberalism and the disciplining of labour. In C. B. Tansel (Ed.), States of discipline: Authoritarian neoliberalism and the contested reproduction of capitalist order (pp. 29-46). Rowman \& Littlefield International Ltd.

Çoban, A. (2004). Community-based ecological resistance: The bergama movement in turkey. Environmental Politics, 13(2), 438-460. https://doi.org/10. 1080/0964401042000209658.

Coleman, L. M. (2013). The making of docile dissent: Neoliberalization and resistance in Colombia and beyond. International Political Sociology, 7(2), 170-187.

Corrales, J. (2015). Autocratic legalism in Venezuela. Journal of Democracy, $26(2), 37-51$.

Crouch, C. (2011). The strange non-death of neoliberalism. Polity Press.

Cudi, R. (2020, June 16). Yeni-Kolonyal Müdahale ve İlhak Diplomasisi - I. Yeni Özgür Politika. Available at: https://www.ozgurpolitika.com/haberiyeni-kolonyal-mudahale-ve-ilhak-diplomasisi-i-1506.

Coşar, S., \& Yeğenoğlu, M. (2011). New grounds for patriarchy in Turkey? Gender policy in the age of AKP. South European Society and Politics, 16(4), 555-573. https://doi.org/10.1080/13608746.2011.571919.

Cumhuriyet. (2014, June 16). Yol kesen PKK'hlar 5 aracı yaktı, 6 kişiyi kaçırd. Retrieved from https://www.cumhuriyet.com.tr/galeri/yol-kesen-pkklilar-5araci-yakti-6-kisiyi-kacirdi-83557.

David, I., \& Toktamiş, Kumru F. (2015). 'Everywhere Taksim': Sowing the seeds for a new Turkey at Gezi. Amsterdam University Press.

Della Porta, D. (2015). Social movements in times of austerity: Bringing capitalism back into protest analysis. Polity Press

Demmers, J., Fernández Jilberto, A. E., \& Hogenboom, B. (Eds.). (2004). Good governance in the era of global neoliberalism: Conflict and depolitisation in Latin America, Eastern Europe, Asia and Africa. Routledge Taylor \& Francis Group.

Dinçer, İ. (2011). The impact of neoliberal policies on historic urban space: Areas of urban renewal in Istanbul. International planning studies, 16(1), 43-60. 
Dinçşahin, Ş. (2012). A symptomatic analysis of the Justice and Development Party's populism in Turkey, 2007-2010. Government and Opposition, 47(4), 618-640.

DİSKAR. (2020, October 9). AKP Döneminde 194 Bin İş̧inin Grevi Yasaklandı! Retrieved from http://arastirma.disk.org.tr/?p=4283.

Dogu, B. (2015). Comparing online alternative and mainstream media in Turkey: Coverage of the tekel workers protest against privatization. International Journal of Communication, 9(1), 630-651.

DoğruHaber. (2014, August 18). Tehdit bildirisi dağıtan PKK araç yaktı. Retrieved from https://dogruhaber.com.tr/haber/141376-tehdit-bildirisidagitan-pkk-arac-yakti/.

Duménil, G., \& Lévy, D. (2004). Capital resurgent: Roots of the neoliberal revolution. Transl. by D. T Jeffers. Harvard University Press.

Dunn, B. (2017). Against neoliberalism as a concept. Capital \& Class, 41(3), $435-454$.

Eder, M. (2010). Retreating state? Political economy of welfare regime change in Turkey. Middle East Law and Governance, 2(2), 152-184.

EnSonHaber. (2015, June 15). PKK Adryaman'da Iss Malineleri Yaktı. Available at: https://www.ensonhaber.com/ic-haber/pkk-adiyamanda-is-makine leri-yakti-2015-06-15.

Erensü, S. (2013). Gezi Direnişinin İlhamın Yerelde Aramak Ii-Gezi Parkı Neden Ağaçlandırlliyor? Bianet. Available at: https://m.bianet.org/bianet/ siyaset/147912-gezi-parki-neden-agaclandiriliyor.

Erensü, S. (2018). Powering neoliberalization: Energy and politics in the making of a new Turkey. Energy Research os Social Science, 41, 148-157.

Erensü, S., \& Alemdaroğlu, A. (2018). Dialectics of reform and repression: Unpacking Turkey's authoritarian "turn." Review of Middle East Studies, 52(1), 16-28.

Erman, T., \& Hatiboğlu, B. (2017). Rendering responsible, provoking desire: Women and home in squatter/slum renewal projects in the Turkish context. Gender, Place \& Culture, 24(9), 1283-1302.

Erol, M. E. (2019) State and Labour under AKP Rule in Turkey: An Appraisal. Journal of Balkan and Near Eastern Studies, 21(6), 663-677. https://doi. org/10.1080/19448953.2018.1506296.

Esen, B., \& Gumuscu, S. (2016). Rising competitive authoritarianism in Turkey. Third World Quarterly, 37(9), 1581-1606.

Fabry, A. (2019). Neoliberalism, crisis and authoritarian-Ethnicist reaction: The ascendancy of the Orbán regime. Competition \& Change, 23(2), 165-191.

Fabry, A., \& Sandbeck, S. (2019). Introduction to special issue on 'authoritarian neoliberalism'. Competition \& Change, 23(2), 109-115. https://doi.org/10. $1177 / 1024529418813827$. 
Fine, B., \& Saad-Filho, A. (2017). Thirteen things you need to know about neoliberalism. Critical Sociology, 43(4-5), 685-706.

Flesher, F. C. (2017). European anti-austerity and pro-democracy protests in the wake of the global financial crisis. Social Movement Studies, 16(1), 1-20.

Freedom House. (2018). Freedom in the World 2018. Available at: https://fre edomhouse.org/report/freedom-world/freedom-world-2018.

Gans, J. (2017). Racialization and racialization research. Ethnic and Racial Studies, 40(3), 341-352.

Geniş, Ş. (Ed.). (2020). Otoriter Neoliberalizmin Gölgesinde: Kent, Mekan, Insan. Nika Yayınevi.

Glassman, J. (2006). Primitive accumulation, accumulation by dispossession, accumulation by 'extra-economic' means. Progress in Human Geography, $30(5), 608-625$.

Gonzales, A. (2016). Neoliberalism, the homeland security state, and the authoritarian turn. Latino Studies, 14(1), 80-98.

Gözler, K. (2016). 1982 Anayasası Hala Yürürlükte mi? Anayasasızlaștırma Üzerine Bir Deneme. Available at: https://www.anayasa.gen.tr/anayasasizla stirma-v4.pdf.

Gürakar, E. Ç. (2016). Politics of favoritism in public procurement in Turkey: Reconfigurations of dependency networks in the AKP era. Springer.

Güzey, Ö. (2016). The last round in restructuring the city: Urban regeneration becomes a state policy of disaster prevention in Turkey. Cities, 50, 40-53.

Hale, W., \& Özbudun, E. (Eds.). (2011). Islamism, democracy and liberalism in Turkey: The case of the AKP. Routledge.

Hart, G. (2006). Denaturalizing dispossession: Critical ethnography in the age of resurgent imperialism. Antipode, 38(5), 977-1004.

Harvey, D. (2006). Neo-liberalism as creative destruction. Geografiska Annaler. Series B, Human geography, 88(2), 145-158.

Hill Collins, P., \& Sirma, B. (2016). Intersectionality (Key concepts). Polity Press.

Holston, J. (2009). Insurgent citizenship in an era of global urban peripheries. City \& Society, 21(2), 245-267.

Huke, N., Clua-Losada, M., \& Bailey, D. J. (2015). Disrupting the European crisis: A critical political economy of contestation, subversion and escape. New Political Economy, 20(5), 725-751.

Hürriyet. (2017, May 7). Bingöl'de PKK'lılar Iss Makinesi Yaktı. Available at: https://www.hurriyet.com.tr/bingolde-pkklilar-is-makinesi-yakti-40450226.

Independent Türkçe. (2021, January 25). Cumburbaşkan Başdanışmam Mebmet Uçum: AİHM kararları esastan bağlayıcı değil, yönlendiricidir. Available at: https://www.indyturk.com/node/305546/haber/cumhurba\%C5\%9Fkan\% C4\%Bl-ba\%C5\%9Fdan\%C4\%Bl\%C5\%9Fman\%C4\%Bl-mehmet-u\%C3\%A7umai\%CC\%87hm-kararlar\%C4\%Bl-esastan-ba\%C4\%9Flay $\%$ C4\%Blc\%C4\%Bl-de $\%$ C4\%9Fil. 
Insel, A. (2003). The AKP and normalizing democracy in Turkey. The South Atlantic Quarterly, 102(2), 293-308.

İnsel, A. (2015). La nouvelle Turquie d'Erdogan: Du rêve démocratique à la dérive autoritaire. La Découverte.

İş Cinayetleri Raporu. (2020). İşçi Sağlığı ve İş Güvenliği Meclisi. Available at: http://www.isigmeclisi.org/site_icerik/2021/locak/l rapor.pdf.

Joseph, J. (2013). Resilience as embedded neoliberalism: A governmentality approach. Resilience, 1(1), 38-52.

Kandiyoti, D., \& Emanet, Z. (2017). Education as battleground: The capture of minds in Turkey. Globalizations, 14(6), 869-876.

Kavak, S. (2016). Rethinking political economy of contemporary water struggles in Turkey: Space, structures and altered agencies from a comparative perspective (Doctoral dissertation). Université Paris-Saclay.

Kavak, S. (2020). Rethinking the political economy of rural struggles in Turkey: Space, structures, and altered agencies. Journal of Agrarian Change, 21, 242262.

Kaya, Ö., \& Öğünç, P. (2020). Chess, hide-and-seek and determination: Civil society in difficult times. Anadolu Kültür. Available at: https://www.anadolukultur.org/_FILES/Contents/991/aksiviltoplumra poru_full_web.pdf?v=20210818101301.

Kaygusuz, Ö. (2018). Authoritarian neoliberalism and regime security in Turkey: Moving to an 'exceptional state' under AKP. South European Society and Politics, 23(2), 281-302.

Keyder, Ç., \& Yenal, Z. (2011). Agrarian change under globalization: Markets and insecurity in Turkish agriculture. Journal of Agrarian Change, 11(1), 6086.

Kivılcım, Z. (2021). The politics of legality in the authoritarian liberal regime in Turkey. In E. Babacan, M. Kutun, E. Pinar, \& Z. Yilmaz (Eds.), Regime change in Turkey: Neoliberal authoritarianism, Islamism and hegemony (pp. 196-212). Routledge.

Konings, M. (2012). Imagined double movements: Progressive thought and the specter of neoliberal populism. Globalizations, 9(4), 609-622.

Korkut, U., \& Sarfati, Y. (2020). The pious dissidence in Turkey: Contesting religious neoliberal governmentality under the AKP. Politics, 40(4), 413-427.

Korolczuk, E. (2016). Neoliberalism and feminist organizing: From "NGOization of resistance" to resistance against neoliberalism. In E. Kováts (Ed.), Solidarity in struggle: Feminist perspectives on neoliberalism in East-Central Europe (pp. 32-41). Friedrich-Ebert-Stiftung.

Kutun, M. (2021). Making the new neo-liberal state in Turkey. In E. Babacan, M. Kutun, E. Pinar, \& Z. Yilmaz (Eds.), Regime change in Turkey: Neoliberal authoritarianism, Islamism and hegemony (pp. 49-67). Routledge. 
Kuymulu, M. B. (2013). Reclaiming the right to the city: Reflections on the urban uprisings in Turkey. City, 17(3) 274-278. https://doi.org/10.1080/ 13604813.2013 .815450 .

Kuyucu, T., \& Unsal, O. (2010). 'Urban transformation' as state-led property transfer: An analysis of two cases of urban renewal in Istanbul. Urban Studies, 47(7), 1479-1499.

Las Heras, J. (2019). International political economy of labour and Gramsci's methodology of the subaltern. British Journal of Politics is International Relations, 21(1), 226-244.

Levi, J. M. (1998). The bow and the blanket: Religion, identity and resistance in Rarámuri material culture. Journal of Anthropological Research, 54(3), 299324.

Lovering, J., \& Turkmen, H. (2011). Bulldozer neo-liberalism in Istanbul: The state-led construction of property markets, and the displacement of the urban poor. International Planning Studies, 16(1), 73-96.

Madra, Y. (2016). AK Parti'nin ikilemli ekonomi politigi: Neoliberal mi, neomerkantilist mi? Baslangic Dergi. Available at: https://baslangicdergi.org/ ak-partinin-ikilemli-ekonomi-politigi-neoliberal-mi-neo-merkantilist-mi/.

Madra, Y. M., \& Yilmaz, S. (2019). Turkey's decline into (Civil) War economy: From neoliberal populism to corporate nationalism. South Atlantic Quarterly, $118(1), 41-59$.

Masquelier, C. (2017). Critique and resistance in a neoliberal age: Towards a narrative of emancipation. Palgrave Macmillan.

Negrón-Gonzales, M. (2016). The feminist movement during the AKP era in Turkey: Challenges and opportunities. Middle Eastern Studies, 52(2), 198214.

Öktem, K., \& Akkoyunlu, K. (2016). Exit from democracy: Illiberal governance in Turkey and beyond. Southeast European and Black Sea Studies, 16(4), 469480 .

Omi, M., \& Winant, H. (2014). Racial formation in the United States (3rd ed.). Routledge.

Ong, A. (2006). Neoliberalism as exception: Mutations in citizenship and sovereignty. Duke University Press.

Önder, N. (1998). Integrating with the global market: The state and the crisis of political representation. International Journal of Political Economy, 28(2), 44-84.

Önder, N. (2016). The economic transformation of Turkey: Neoliberalism and state intervention. I.B. Tauris.

Önis, Z. (2011). Power, interests and coalitions: The political economy of mass privatisation in Turkey. Third World Quarterly, 32(4), 707-724.

Öniş, Z. (2013). Sharing power: Turkey's democratization challenge in the age of the AKP hegemony. Insight Turkey, 15(2), 103-122. 
Özbay, C., Erol, M., Türem, Z. U., \& Terzioglu, A. (Eds.). (2015). The making of neoliberal Turkey. Routledge.

Özbudun, E. (2006). From political Islam to conservative democracy: The case of the Justice and Development Party in Turkey. South European Society and Politics, 11(3-4), 543-557.

Özbudun, E. (2007). Democratization reforms in Turkey, 1993-2004. Turkish Studies, 8(2), 179-196.

Özbudun, E. (2014). AKP at the crossroads: Erdoğan's majoritarian drift. South European Society and Politics, 19(2), 155-167.

Özbudun, E. (2015). Turkey's judiciary and the drift toward competitive authoritarianism. The International Spectator, 50(2), 42-55.

Özden, B. A. (2014). The transformation of social welfare and politics in Turkey: A successful convergence of neoliberalism and populism. In İ Akça, A. Bekmen, \& B. A. Özden (Eds.), Turkey reframed: Constituting neoliberal hegemony (pp. 157-173). Pluto Press.

Özden, B. A., Akça, I., \& Bekmen, A. (2017). Anatomies of authoritarian neoliberalism in Turkey: The Justice and Development Party era. In C. B. Tansel (Ed.), States of discipline: Authoritarian neoliberalism and the contested reproduction of capitalist order (pp. 189-210). Rowman \& Littlefield International Ltd.

Özdoğan, N. (2021). Sivil Toplumu Tehdit ve Tenkil Yasası. Birikim. https:// birikimdergisi.com/guncel/10424/sivil-toplumu-tehdit-ve-tenkil-yasasi.

Özkiziltan, D. (2019). Authoritarian neoliberalism in AKP's Turkey: An industrial relations perspective. Industrial Relations Journal, 50(3), 218-239.

Peck, J., \& Tickell, A. (2002). Neoliberalizing space. Antipode, 34(3), 380-404. Pinar, E. (2021). A labour-oriented perspective on regime discussion in Turkey. In E. Babacan, M. Kutun, E. Pinar, \& Z. Yilmaz (Eds.), Regime change in Turkey: Neoliberal authoritarianism, Islamism, and hegemony (pp. 32-48). Routledge.

Porta, D., \& Atak, K. (2015). The police. In J. Duyvendak \& J. Jasper (Eds.), Breaking down the state (pp. 113-132). Amsterdam University Press.

Poulantzas, N. (1978/2014). State, power, socialism, (Trans. by P. Camiller). New Left Books.

Purkis, S. (2016). Istanbul'da Insaat Odakli Birikimin Durdurulamayan Yukselisi: Konut Fazlasina Karsin Artan Konut Acigi. Mulkiye Dergisi, 40(4), 91-112.

Roy, A. (2014). The NGO-ization of resistance. Massalijn. Available at: http:// massalijn.nl/new/the-ngo-ization-of-resistance/. Accessed 30 June 2020.

Rutherford, A. (2018). Feminism, psychology, and the gendering of neoliberal subjectivity: From critique to disruption. Theory \& Psychology, 28(5), 619644.

Ryan, M. D. (2019). Interrogating 'authoritarian neoliberalism': The problem of periodization. Competition \& Change, 23(2), 116-137. 
Saad-Filho, A. (2020). Brazilian democracy confronts authoritarian neoliberalism. In A. Saad-Filho (Ed.), Growth and change in neoliberal capitalism (pp. 356369). Brill.

Saraçoğlu, D. Ş, Memiş, E., Voyvoda, E., \& Kızılırmak, B. (2018). Changes in global trade patterns and women's employment in manufacturing, 19952011. Feminist Economics, 24(3), 1-28.

Sayarı, S. (2016). Back to a predominant party system: The November 2015 snap election in Turkey. South European Society and Politics, 21(2), 263-280.

Scheppele, K. L. (2018). Autocratic legalism. The University of Chicago Law Review, 85, 545-583.

Schneider, E., \& Sandbeck, S. (2019). Monetary integration in the Eurozone and the rise of transnational authoritarian statism. Competition \& Change, 23(2), 138-164.

Scott, J. C. (1985). Weapons of the weak: Everyday forms of peasant resistance. Yale University Press.

Selçuk, O. (2016). Strong presidents and weak institutions: Populism in Turkey, Venezuela and Ecuador. Southeast European and Black Sea Studies, 16(4), 571-589.

Shukaitis, S. (2007). Plan 9 from the capitalist workplace: Insurgency, originary accumulation, rupture. Situations: A Project of the Radical Imagination, 2(2), 95-116.

Smith, C. (2018). Race and the logic of radicalisation under neoliberalism. Journal of Sociology, 54(1), 92-107.

Somer, M. (2016). Understanding Turkey's democratic breakdown: Old vs. new and indigenous vs. global authoritarianism. Journal of Southeast European and Black Sea Studies, 16(4), 481-503.

Sözen, Y. (2008). Turkey between tutelary democracy and electoral authoritarianism. Private View, 13, 78-84.

Sözen, Y. (2019). Competition in a populist authoritarian regime: The June 2018 dual elections in Turkey. South European Society and Politics, 24(3), 287-315.

Sözen, Y. (2020a). Popular will against democracy: Populist autocratization in Turkey. Reflektif Journal of Social Sciences, 1(1), 9-30.

Sözen, Y. (2020b). Studying autocratization in Turkey: Political institutions, populism, and neoliberalism. New Perspectives on Turkey, 63, 209-235.

Springer, S. (2009). Renewed authoritarianism in Southeast Asia: Undermining democracy through neoliberal reform. Asia Pacific Viewpoint, 50(3), 271276.

Tansel, C. B. (2017). Authoritarian neoliberalism: Towards a new research agenda. In C. B. Tansel (Ed.), States of discipline: Authoritarian neoliberalism and the contested reproduction of capitalist order (pp. 1-28). Rowman \& Littlefield International Ltd. 
Tansel, C. B. (2018). Authoritarian neoliberalism and democratic backsliding in Turkey: Beyond the narratives of progress. South European Society and Politics, 23(2), 197-217.

Taş, H. (2015). Turkey-From tutelary to delegative democracy. Third World Quarterly, 36(4), 776-791. https://doi.org/10.1080/01436597.2015.102 4450.

Taşkın, Y. (2013). Hegemonizing conservative democracy and the problems of democratization in Turkey: Conservatism without democrats? Turkish Studies, 14(2), 292-310.

Theodore, N., Peck, J., \& Brenner, N. (2012). Neoliberal kentçilik: Kentler ve piyasanın egemenliği. İdealKent: Kent Araştırmaları Dergisi (Transl. by S. Genis), 7, 21-37.

Topak, Ö. E. (2019) The authoritarian surveillant assemblage: Authoritarian state surveillance in Turkey. Security Dialogue, 50(5), 454-472. https://doi.org/ $10.1177 / 0967010619850336$.

Tuğal, C. (2016). The fall of the Turkish model: How the Arab uprisings brought down Islamic liberalism. Verso.

Turkey Electricity Transmission Company (TEIAŞ). (2020). Aralik 2020 Kurulu Guc Raporu. Retrieved from https://www.teias.gov.tr/tr-TR/kurulu-guc-rap orlari.

Turkun, A. (2011). Urban regeneration and hegemonic power relationships. International Planning Studies, 16(1), 61-72.

Türkmen, B. (2009). A transformed Kemalist Islam or a new Islamic civic morality? A study of 'religious culture and morality' textbooks in the Turkish high school curricula. Comparative Studies of South Asia, Africa and the Middle East, 29(3), 381-397.

Türkmen, N. (2012). Eylemden Öğrenmek: TEKEL Direnişi ve Sinff Bilinci. İletişim Yayınları.

Türmen, R. (2021). AİHM Kararları Bağlayıcı Mı?. T24, https://t24.com.tr/ yazarlar/riza-turmen/aihm-kararlari-baglayici-mi,29692.

Türkmen-Dervişoğlu, G. (2015, December 11). Turkey: From "role model" to "illiberal democracy". Open Democracy. Available at: https://www.ope ndemocracy.net/en/can-europe-make-it/turkey-from-role-model-to-illiberaldemocracy/.

Turner, R. S. (2011). Neo-liberal ideology: History, concepts and policies. Edinburgh University Press.

Ünsaldi, L. (2013). Religion: Alternatives to technocratic and neoliberal development? In G. Carbonnier, M. Kartas, \& K. T. Silva (Eds.), International development policy: Religion and development. Palgrave Macmillan. https:// doi.org/10.1057/9781137329387_11.

Uyar Mura, E. S. (2021). Hosting overnight guests: Gendered unpaid work as a solidarity mechanism of migrants in the process of urbanization in Turkey. 
Social Politics: International Studies in Gender, State \& Society, jxab002. https://doi.org/10.1093/sp/jxab002.

Venugopal, R. (2015). Neoliberalism as concept. Economy and Society, 44(2), 165-187.

Wacquant, L. (1999). How penal common sense comes to Europeans: Notes on the transatlantic diffusion of the neoliberal Doxa. European Societies, 1(3), 319-352.

Walby, S. (2018). Is Europe cascading into fascism? Addressing key concepts including gender and violence. Politics and Governance, 6(3), 67-77.

Wigger, A., \& Buch-Hansen, H. (2015). EU competition regulation: A case of authoritarian neo-liberalism? In P. F. Kjaer \& E. Hartmann (Eds.), The evolution of intermediary institutions in Europe (pp. 81-98). Palgrave Macmillan UK.

World Bank. (2020). Retrieved from https://ppi.worldbank.org/en/snapshots/ rankings.

Yabanci, B. (2016). Populism as the problem child of democracy: The AKP's enduring appeal and the use of meso-level actors. Southeast European and Black Sea Studies, 16(4), 591-617.

Yabanci, B. (2019). Turkey's tamed civil society: Containment and appropriation under a competitive authoritarian regime. Journal of Civil Society, 15(4), 285306. https://doi.org/10.1080/17448689.2019.1668627.

Yabanci, B., \& Taleski, D. (2018). Co-opting religion: How ruling populists in Turkey and Macedonia sacralise the majority. Religion, State \& Society, 46(3), 283-304.

Yalman, G. L., \& Topal, A. (2019). Labour containment strategies and working class struggles in the neoliberal era: The case of TEKEL workers in Turkey. Critical Sociology, 45(3), 447-461.

Yeldan, E. (2016). Küreselleşme sürecinde Türkiye ekonomisi: bölüşüm, birikim ve büyüme. İletişim Yayınları.

Yeşil, B. (2018). Authoritarian turn or continuity? Governance of media through capture and discipline in the AKP era. South European Society and Politics, 23(2), 239-257.

Yildirim, D. (2009). JDP neoliberal populism (in Turkish). In I. Uzgel \& B. Dura (Eds.), The JDP book: The balance sheet of a transformation. Phoenix Yayınevi.

Yılmaz, Z. (2020). Erdoğan's presidential regime and strategic legalism: Turkish democracy in the twilight zone. Southeast European and Black Sea Studies, 20(2), 265-287.

Yörük, E. (2014). The long summer of Turkey: The Gezi uprising and its historical roots. The South Atlantic Quarterly, 113(2), 419-426.

Yükseker, D. (2009). Neoliberal restructuring and social exclusion in Turkey. In Z. Onis \& F. Senses (Eds.), Turkey and the global economy: Neo-liberal 
restructuring and integration in the post-crisis era (1st ed., pp. 262-280). Routledge.

Open Access This book is licensed under the terms of the Creative Commons Attribution 4.0 International License (http://creativecommons.org/licenses/ by $/ 4.0 /)$, which permits use, sharing, adaptation, distribution and reproduction in any medium or format, as long as you give appropriate credit to the original author(s) and the source, provide a link to the Creative Commons license and indicate if changes were made.

The images or other third party material in this book are included in the chapter's Creative Commons license, unless indicated otherwise in a credit line to the material. If material is not included in the chapter's Creative Commons license and your intended use is not permitted by statutory regulation or exceeds the permitted use, you will need to obtain permission directly from the copyright holder.

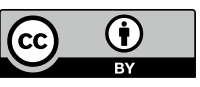

